\title{
Article \\ Catalytic Pyrolysis of Lignin Model Compounds (Pyrocatechol, Guaiacol, Vanillic and Ferulic Acids) over Nanoceria Catalyst for Biomass Conversion
}

\author{
Nataliia Nastasiienko ${ }^{1, *(D)}$, Tetiana Kulik ${ }^{1, *(D)}$, Borys Palianytsia ${ }^{1}$, Julia Laskin ${ }^{2}$, Tetiana Cherniavska ${ }^{1}$, \\ Mykola Kartel ${ }^{1}$ and Mats Larsson ${ }^{3}$
}

check for updates

Citation: Nastasiienko, N.; Kulik, T.; Palianytsia, B.; Laskin, J.;

Cherniavska, T.; Kartel, M.; Larsson, M. Catalytic Pyrolysis of Lignin Model Compounds (Pyrocatechol, Guaiacol, Vanillic and Ferulic Acids) over Nanoceria Catalyst for Biomass Conversion. Appl. Sci. 2021, 11, 7205. https://doi.org/10.3390/app11167205

Academic Editor:

María Atienza-Martínez

Received: 1 July 2021

Accepted: 28 July 2021

Published: 5 August 2021

Publisher's Note: MDPI stays neutral with regard to jurisdictional claims in published maps and institutional affiliations.

Copyright: (C) 2021 by the authors. Licensee MDPI, Basel, Switzerland. This article is an open access article distributed under the terms and conditions of the Creative Commons Attribution (CC BY) license (https:/ / creativecommons.org/licenses/by/ $4.0 /)$.
1 Chuiko Institute of Surface Chemistry, NAS of Ukraine, 17 General Naumov Str., 03164 Kyiv, Ukraine; borbor@i.ua (B.P.); t-cherniavska@ukr.net (T.C.); nikar@kartel.kiev.ua (M.K.)

2 Department of Chemistry, Purdue University, West Lafayette, IN 47907, USA; jlaskin@purdue.edu

3 Department of Physics, AlbaNova University Center, Stockholm University, SE-106 91 Stockholm, Sweden; ml@fysik.su.se

* Correspondence: nastasienkon@ukr.net (N.N.); tanyakulyk.isc.ms@gmail.com (T.K.); Tel.: +38-044-422-9676 (N.N. \& T.K.)

\begin{abstract}
Understanding the mechanisms of thermal transformations of model lignin compounds (MLC) over nanoscale catalysts is important for improving the technologic processes occurring in the pyrolytic conversion of lignocellulose biomass into biofuels and value-added chemicals. Herein, we investigate catalytic pyrolysis of MLC (pyrocatechol (P), guaiacol (G), ferulic (FA), and vanillic acids (VA)) over nanoceria using FT-IR spectroscopy, temperature-programmed desorption mass spectrometry (TPD MS), and thermogravimetric analysis (DTG/DTA/TG). FT-IR spectroscopic studies indicate that the active groups of aromatic rings of $\mathrm{P}, \mathrm{G}, \mathrm{VA}$, and FA as well as carboxylate groups of VA and FA are involved in the interaction with nanoceria surface. We explore the general transformation mechanisms of different surface complexes and identify their decomposition products. We demonstrate that decomposition of carboxylate acid complexes occurs by decarboxylation. When FA is used as a precursor, this reaction generates 4-vinylguaiacol. Complexes of VA and FA formed through both active groups of the aromatic ring and decompose on the $\mathrm{CeO}_{2}$ surface to generate hydroxybenzene. The formation of alkylated products accompanies catalytic pyrolysis of acids due to processes of transalkylation on the surface.
\end{abstract}

Keywords: kinetics and mechanisms; bio-oil upgrading; kinetic parameters; 4-vinylguaiacol; surface complex; FT-IR spectroscopy; temperature-programmed desorption mass spectrometry

\section{Introduction}

Lignocellulose feedstock is a major potential renewable source of bio-oils and a large number of valuable chemicals. A total of $10-25 \%$ of lignocellulosic raw material is lignin [1]. The exact structure of lignin is still unknown; however, it is believed that lignin is formed through biosynthesis of $p$-coumaryl alcohol, coniferyl alcohol, and sinapyl alcohol [2]. Lignin determines the strength of trunks and stems of plants [3]. Due to its rigid structure, this natural polymer is currently used mainly for heat and energy production [4-7]. However, the growing amount of research on the production of bio-oil and various chemicals from lignocellulosic raw materials motivates the search for effective ways to process lignin $[4,5,7]$.

Due to its unique structure, lignin can be a source of a large number of aromatic compounds, both monomers and polymers [1,8,9]. Since the structure of this natural polymer is extremely complex, model compounds are often used to study its conversion to high value-added chemicals [8,10]. Ferulic and vanillic acids, as well as pyrocatechol and guaiacol are common products of lignin processing [1,8,11-13], and therefore are often used as model lignin compounds $[4,8,11,14-17]$. These compounds are lignin structural units of 
various sizes and contain almost the entire list of functional groups present in the lignin macromolecule. Among these products, guaiacol is an ideal model compound for assessing the performance of various catalysts, as it is a typical component of pyrolysis oil and one of the most complex methoxyphenols for deoxygenation $[18,19]$. Pyrocatechol is often an intermediate in converting other model lignin compounds, for example, guaiacol $[8,20]$. Ferulic acid may be used for the production of valuable aromatic chemicals, in particular 4-vinylguaiacol [20-24], vanillin, and vanillic acid [24-26].

In addition to lignin, these compounds are found in large quantities in other polymers of vegetable raw materials and in the waste generated during their processing (winedistilleries, olive oil processing, table olive industries, pulp paper processing, etc.) [26-29]. Due to the high toxicity of phenol-containing compounds to microorganisms [29-31], special attention is directed to their utilization [24,32].

Pyrolysis is commonly used for lignin processing due to its ability to effectively separate this polymer's strong structure $[8,11,33,34]$. However, high-temperature conversion of these raw materials generates a large number of final pyrolysis products. Various catalytic systems are used to overcome these imperfections [34]. $\mathrm{CeO}_{2}$ is often used as a catalyst in the catalytic conversions of lignocellulosic raw materials [35-40]. Its catalytic properties are attributed to the ease with which it alternates between the $3+$ and 4+ oxidation states, depending on the environmental conditions. [35]. The corresponding number of oxygen vacancies compensates for the decrease in the positive charge of $\mathrm{Ce}^{3+}$. The concentration of defects, both $\mathrm{Ce}^{3+}$ ions and oxygen vacancies, on the oxide surface is higher than in the bulk [41]. Therefore, nanosized cerium oxide has higher concentrations of $\mathrm{Ce}^{3+}$ ions and, accordingly, redox activity compared to large particles, since the surface-to-volume ratio increases [42]).

In the conversion and valorization of lignocellulosic raw materials and model compounds of lignin, cerium oxide is combined with other catalysts, particularly metals [38,39] and zirconium oxide [16,35,43]. In the work of Deng and co-authors [32], $\mathrm{CeO}_{2}$ oxide with platinum deposited on its surface was used for the oxidative conversion of lignin and 2-phenoxy-1-phenyl-ethanol, which contains $\beta$-O-4 bonds and $\mathrm{C} \alpha$-hydroxyl groups, in monomeric aromatic compounds (4-methoxy-phenol, acetophenone, methyl benzoate (82\%, $38 \%$, and $40 \%$ ). $\mathrm{Pt} / \mathrm{CeO}_{2}$ catalysts have also been used to convert 4-propyl-phenol to propylcyclohexane. [37]. The yield of propyl-cyclohexane was $83 \%$, and propyl-cyclohexanol was $<1 \%$. In this case, the catalyst worked effectively both in the presence of water and in anhydrous conditions [37].

Catalytic systems composed of both $\mathrm{CeO}_{2}$ and $\mathrm{ZrO}_{2}$ have proven their effectiveness $[16,35,38,43]$. They have many advantages over the individual oxides [35]. In particular, the combination of $\mathrm{CeO}_{2}$ and $\mathrm{ZrO}_{2}$ promotes a decrease in the required surface temperature and reduction volume as well as an increase in the number of oxygen vacancies. Such catalytic systems dissociate hydrogen and create oxygen vacancies under mild conditions. The inclusion of zirconium ions in the cerium lattice leads to structural compression and promotes the formation of oxygen vacancies. In addition, the presence of zirconium partially suppresses crystallization during the synthesis of catalysts and leads to the formation of small and active crystallites [35].

Using a $\mathrm{CeO}_{2} / \mathrm{ZrO}_{2}$ catalyst for the hydrodeoxygenation of guaiacol [35], valuable products such as phenol, catechol, and benzene were obtained. In addition, the use of this catalytic system increased the conversion efficiency of guaiacol and eliminated the formation of the undesirable oligomeric products containing hydrogenated rings. Moreover, these catalysts showed no signs of deactivation after $72 \mathrm{~h}$ of flow [35].

The efficiency of $\mathrm{CeO}_{2}, \mathrm{CeO}_{2}-\mathrm{ZrO}_{2}, \mathrm{Ni} / \mathrm{CeO}_{2}$, and $\mathrm{Ni} / \mathrm{CeO}_{2}-\mathrm{ZrO}_{2}$ catalysts for hydrodeoxygenation of phenol at intermediate temperature and pressure $\left(275^{\circ} \mathrm{C}\right.$ and $\left.100 \mathrm{bar}\right)$ in a batch reactor was tested in [43]. Oxide catalysts $\left(\mathrm{CeO}_{2}, \mathrm{CeO}_{2} / \mathrm{ZrO}_{2}\right)$ showed low activity on the hydrodeoxygenation of phenol under these conditions due to their inability to hydrogenate the phenolic ring [43]. Reduced metal catalysts for both noble and base metals were significantly more active. Hydrodeoxygenation of phenol proceeded through 
initial hydrogenation to cyclohexanone, which rapidly hydrogenates to cyclohexanol [43]. $\mathrm{Ni} / \mathrm{CeO}_{2}$ and $\mathrm{Ni} / \mathrm{CeO}_{2}-\mathrm{ZrO}_{2}$ were the most active catalysts for the initial hydrogenation of phenol to cyclohexanol but were insufficiently active in the next stage of deoxygenation [43].

Catalysts $\mathrm{CeO}_{2}, \mathrm{ZrO}_{2}, \mathrm{Al}_{2} \mathrm{O}_{3}, \mathrm{CeO}_{2}-\mathrm{SiO}_{2}$, and $\mathrm{CeO}_{2}-\mathrm{ZrO}_{2}$ were used in the ketonization of valeric acid into 5-nonanone, [44-46] and various fatty acids $\left(\mathrm{C}_{2}-\mathrm{C}_{10}, \mathrm{D}_{6} \mathrm{CCOOH}\right.$, and $\mathrm{CH}_{3} \mathrm{COOH}$ ) into symmetric ketones [46]. The majority of the studied acids [46], especially valeric, acetic, levulinic, furandicarboxylic, and other acids, can be obtained by converting lignocellulosic biomass [47]. Conversely, lignin is a source for a number of natural cinnamic acids $[1,48]$.

In [38], the activity and surface properties based on oxides of $\mathrm{CeO}_{2}$ and $\mathrm{ZrO}_{2}$ coated with nickel $\left(\mathrm{Ni} / \mathrm{CeO}_{2}-\mathrm{ZrO}_{2}\right)$ were used in the thermochemical conversion of cellulose. The catalyst $\mathrm{Ni} / \mathrm{CeO}_{2}-\mathrm{ZrO}_{2}$ was effective in producing hydrogen during the conversion of cellulose raw materials. The presence of cerium oxide in such catalytic systems contributed to a slower decrease in their activity versus $\mathrm{Ni} / \mathrm{ZrO}_{2}$. It has been shown [38] that the tested catalysts allow the efficient formation of a gaseous fraction [38]. At the same time, in studies [16], $\mathrm{Ni} / \mathrm{CeO}_{2}-\mathrm{ZrO}_{2}$ catalytic systems were used for lignin conversion. The main phenolic compounds in the obtained lignin oil were: guaiacol, methylguaiacol, ethylguaiacol, vanillin, and homovanillic acid [16]. However, the exact mechanisms of the transformations that occurred remain unclear.

In this work, we examined thermal transformations of several aromatic model compounds of lignin (guaiacol, pyrocatechol, vanillic acid, and ferulic acid) over the nanoceria catalyst. The results reported in this study are important for establishing the catalytic transformation mechanisms of both lignin and its processing products and other phenolcontaining plant raw materials over the $\mathrm{CeO}_{2}$-based catalytic systems.

\section{Materials and Methods}

The model compounds used in this work were pyrocatechol (99\%, Changzhou Winsun Import \& Export Co., Ltd, Changzhou, Jiangsu, China), guaiacol ( $\geq 98 \%$, Alfa Aesar, Karlsruhe, Germany), vanillic acid (97\%, Sigma-Aldrich, Buchs, Switzerland) and ferulic acid (98\%, Alfa Aesar, Karlsruhe, Germany). No further purification of these compounds was conducted in this work. Nanosized cerium dioxide $\left(99.5 \%, \mathrm{~S}_{\mathrm{Ar}}=71 \mathrm{~m}^{2} / \mathrm{g}\right.$, Alfa Aesar, Karlsruhe, Germany) was pre-calcined at $500{ }^{\circ} \mathrm{C}$ for $2 \mathrm{~h}$ to remove organic matter.

A series of samples, $\mathrm{P} / \mathrm{CeO}_{2}, \mathrm{G} / \mathrm{CeO}_{2}, \mathrm{VA} / \mathrm{CeO}_{2}$, and $\mathrm{FA} / \mathrm{CeO}_{2}$, with concentrations of phenolic compounds of $0.1,0.3,0.6,0.9$, and $1.2 \mathrm{mmol} / \mathrm{g}$ were prepared. The concentration range of $0.1-1.2 \mathrm{mmol} / \mathrm{g}$ was selected based on previous studies [49]. According to [49], the maximum adsorption values for cinnamic acid and its derivatives, including ferulic acid, are almost equal and amount to $\approx 2.9 \times 10^{-4} \mathrm{~mol} / \mathrm{g}$ irrespective of the differences in the reaction sites of their molecules. The samples were prepared by impregnation of $100 \mathrm{mg}$ of $\mathrm{CeO}_{2}$ with $2 \mathrm{~mL}$ of $\mathrm{P}, \mathrm{G}, \mathrm{VA}$, and FA solutions in ethanol. The suspensions were stirred for several minutes and then dried at room temperature in the air.

Infrared spectra were recorded on a Thermo Nicolet Nexus FT-IR instrument (Thermo Nicolet Corporation, Madison, WI, USA) within the range of $4000-400 \mathrm{~cm}^{-1}$, working in diffuse reflection mode. The resolution was $4 \mathrm{~cm}^{-1}$, scanning speed $-0.5 \mathrm{~cm} / \mathrm{s}$, and number of scans-50. Before the FTIR studies, pure $\mathrm{CeO}_{2}$ and samples $\mathrm{P} / \mathrm{CeO}_{2}, \mathrm{G} / \mathrm{CeO}_{2}$, $\mathrm{VA} / \mathrm{CeO}_{2}$, and $\mathrm{FA} / \mathrm{CeO}_{2}$ were mixed with $\mathrm{KBr}(\geq 99 \%$, Alfarus, Kyiv, Ukraine) (1:10). $\mathrm{KBr}$ was pre-calcined for $2 \mathrm{~h}$ at $500{ }^{\circ} \mathrm{C}$. Pure phenolic compounds were mixed with $\mathrm{KBr}$ in a ratio of 1:100.

The TPD MS-experiment was performed on an MX-7304 monopole mass spectrometer (Electron, Sumy, Ukraine) with electron ionization, re-equipped for thermal desorption measurements $[45,46,50]$. At the beginning of the experiment, a sample weighing 10-20 mg was placed in a quartz-molybdenum ampoule and pumped out at room temperature to a pressure of $\sim 5 \times 10^{-5} \mathrm{~Pa}$. The rate of programmed linear heating was $0.17^{\circ} \mathrm{C} / \mathrm{s}$. Heating was increased from room temperature to $750^{\circ} \mathrm{C}$. Volatile products of thermolysis entered the ionization chamber of the mass spectrometer and were ionized and fragmented under 
the action of electrons. The range of the investigated masses was 1-210 a.m.u. The total number of mass spectra recorded during the experiment reached $\sim 240$. The slow heating of the sample and the high pumping rate of volatile thermolysis products made it possible to neglect diffusion effects. Under such conditions, the intensity of the ion current was proportional to the rate of desorption.

Kinetic parameters of the chemical reactions and processes of the lignin model compound on the nanoceria surface (temperature of the maximum desorption rate $\mathrm{T}_{\max }$, reaction order $n$, activation energy $E^{f}$, pre-exponential factor $v_{0}$, and change of activation entropy $\Delta S^{\neq}$) were calculated from the TPD-MS data by an in-house computer program using the linear form of the Arrhenius equation [45,46,50].

Thermogravimetric analysis, differential thermogravimetric analysis (DTG), and differential thermal analysis (DTA) were performed using a TGA/DTA analyzer (Q-1500D, Hungary). Samples weighing $100 \mathrm{mg}$ were heated from room temperature to $1000{ }^{\circ} \mathrm{C}$. The heating rate was $10^{\circ} \mathrm{C} / \mathrm{min}$ in an air atmosphere.

\section{Results and Discussion}

\subsection{FT-IR Spectroscopic Studies}

\subsubsection{Pyrocatechol}

FTIR spectra of $\mathrm{CeO}_{2}$, pure $\mathrm{P}$, and samples $\mathrm{P} / \mathrm{CeO}_{2}$ are presented in Figure 1. Interpretation of the obtained results, performed on the basis of experimental data [51,52] and the results of quantum chemical calculations of the frequencies of normal vibrations of pyrocatechol in the crystalline and gaseous states [53], are presented in Table 1. The symbol $v$ is used to denote valence vibrations, $\beta$ for out-of-plane deformation vibrations, and $\delta$ for non-planar deformation vibrations.

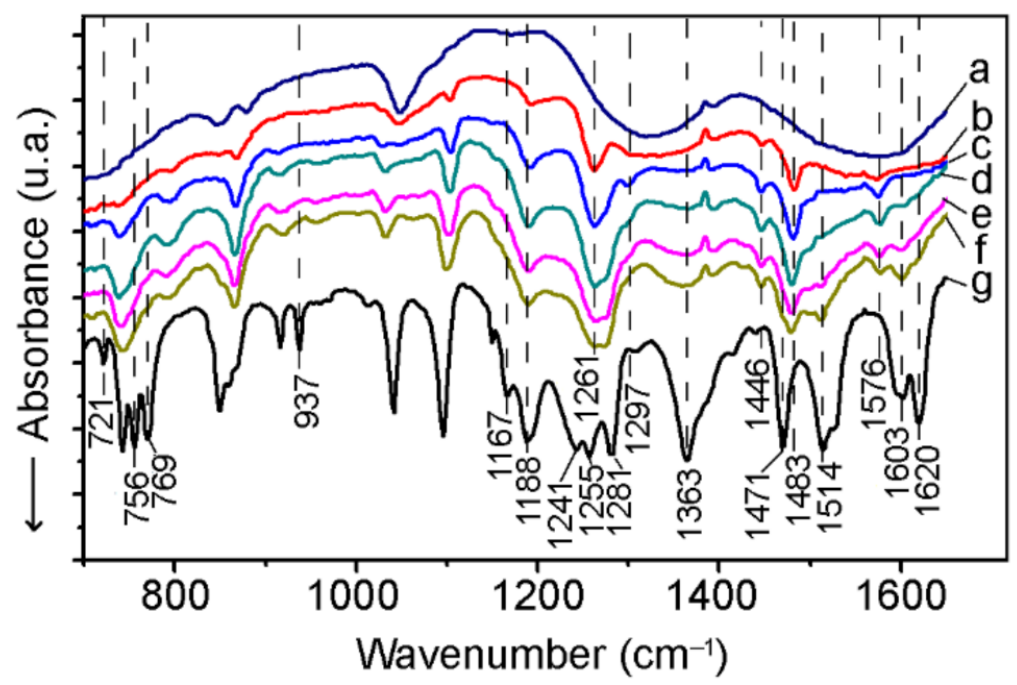

Figure 1. Fourier transform-infrared (FT-IR) spectra of pure $\mathrm{CeO}_{2}(\mathrm{a})$, samples of $\mathrm{P} / \mathrm{CeO}_{2}$ with different contents of FA (0.1: b; 0.3: c; 0.6: d; 0.9: e; $1.2 \mathrm{mmol} / \mathrm{g}: \mathrm{f})$ and pure $\mathrm{P}(\mathrm{g})$. 
Table 1. Assignments of infrared bands of pure $\mathrm{P}$ and of $\mathrm{P} / \mathrm{CeO}_{2}(0.6 \mathrm{mmol} / \mathrm{g})$.

\begin{tabular}{|c|c|c|c|}
\hline \multirow{2}{*}{ Assignments } & \multicolumn{2}{|c|}{ Frequency $\left(\mathrm{cm}^{-1}\right)$} & \multirow{2}{*}{ Ref. } \\
\hline & $\mathbf{P}$ & $\mathrm{P} / \mathrm{CeO}_{2}$ & \\
\hline$\beta(\mathrm{CH})$ & 721 & - & [53] \\
\hline$\beta(\mathrm{CH})$ & 937 & - & [53] \\
\hline$\delta(\mathrm{OH})+\delta(\mathrm{CH}))$ & 756 & - & [53] \\
\hline$v(C C)+v(C O)+\beta(C C C))$ & 769 & - & [53] \\
\hline$v(\mathrm{CO})+v(\mathrm{CC})+\beta(\mathrm{CCH})$ & 1167 & - & [53] \\
\hline$\beta(\mathrm{CCH})+v(\mathrm{CC})+\beta(\mathrm{COH})$ & 1188 & 1188 & {$[51,53]$} \\
\hline$\beta(\mathrm{CCH})+\beta(\mathrm{COH})+\gamma(\mathrm{CC})$ & 1242 & - & [53] \\
\hline$\beta(\mathrm{CCH})+\beta(\mathrm{COH})+\gamma(\mathrm{CC})$ & 1255 & 1261 & {$[51,53]$} \\
\hline$v(C C)+v(C O)+\beta(C C C)$ & 1281 & - & {$[51,53]$} \\
\hline$\beta(\mathrm{CCH})+\beta(\mathrm{COH})+\gamma(\mathrm{CC})$ & 1363 & 1361 & [53] \\
\hline$\beta(\mathrm{COH})+v(\mathrm{CO})$ & - & 1273 * & \\
\hline$v(\mathrm{CO})^{-}$ & - & 1297 & \\
\hline$\beta(\mathrm{CCH})+\gamma(\mathrm{CC})+\beta(\mathrm{COH})+\beta(\mathrm{CCO})$ & 1440 & 1446 & [53] \\
\hline$v(\mathrm{CC})+\beta(\mathrm{CH})$ & 1471 & - & [53] \\
\hline$v(\mathrm{CC})+\beta(\mathrm{CH})$ & - & 1483 & \\
\hline$v(\mathrm{CC})+\beta(\mathrm{CH})$ & 1514 & 1514 * & [53] \\
\hline$v(\mathrm{CC})+\beta(\mathrm{CH})$ & - & 1576 & \\
\hline$v(\mathrm{CC})+\beta(\mathrm{CH})$ & 1603 & $1603 *$ & [53] \\
\hline$v(\mathrm{CC})+\beta(\mathrm{CH})$ & 1620 & - & [53] \\
\hline
\end{tabular}

* band appears for P concentrations $>0.6 \mathrm{mmol} / \mathrm{g}$.

According to [53], most of the bands of this dihydroxybenzene have a mixed shape. Figure 1 shows significant changes in the $\mathrm{P} / \mathrm{CeO}_{2}$ spectra compared with pure $\mathrm{P}$ (Figure 1 , Table 1), which is the result of the interaction of $\mathrm{P}$ molecules with oxide. The absorption bands at 721 and $937 \mathrm{~cm}^{-1}$, which correspond to $\mathrm{C}-\mathrm{H}$ stretching vibrations [53] of pure pyrocatechol molecules in the crystalline state, are a sign of association due to intermolecular hydrogen bonds [53]. The disappearance of these absorptions for $\mathrm{P} / \mathrm{CeO}_{2}$ indicates the destruction of this association structure of $\mathrm{P}$ due to interaction with the oxide surface.

The obtained spectra of the studied samples contain several other features indicating the interaction of $\mathrm{OH}$ groups of pyrocatechol with $\mathrm{CeO}_{2}$. In particular, one of these signs is a significant decrease in the intensity of the bands $756(\delta(\mathrm{OH})+\delta(\mathrm{CH}))$ and $769 \mathrm{~cm}^{-1}$ $(v(\mathrm{CC})+v(\mathrm{CO})+\beta(\mathrm{CCC}))[53]$.

There are bands 849 and $859 \mathrm{~cm}^{-1}$ (Figure 1) for pyrocatechol in the region of $800-900 \mathrm{~cm}^{-1}$, which according to $[48,53]$, are mixed and associated with non-planar deformation vibrations of $\mathrm{CH}$, deformation vibrations of $\mathrm{CC}$, as well as vibrations of $\mathrm{COH}$ groups. For $\mathrm{P} / \mathrm{CeO}_{2}$ samples, changes in this region of the spectrum are observed due to the interaction of $\mathrm{OH}$ groups of $\mathrm{P}$ with the oxide surface. Absorption at $1041 \mathrm{~cm}^{-1}$ for pyrocatechol is mainly due to the stretching vibrations of the $\mathrm{CC}$, and $1095 \mathrm{~cm}^{-1}$ is associated with vibrations of $\mathrm{CC}, \mathrm{CH}$, and $\mathrm{COH}$ groups. For $\mathrm{P} / \mathrm{CeO}_{2}$ samples, these bands are shifted toward lower frequencies, and their relative intensity decreases.

In addition, for $\mathrm{P} / \mathrm{CeO}_{2}$ samples, changes were found in the range $1150-1400 \mathrm{~cm}^{-1}$. This region's absorption mainly corresponds to stretching and bending vibrations of $\mathrm{COH}[51,53]$.

Analysis of the IR spectra of pyrocatechol in the crystalline state and the gas phase [48] shows that the ultrathin structure of the bands in this region is associated with the formation of intermolecular and intramolecular bonds. From Figure 1, it is seen that the maximum of $1167 \mathrm{~cm}^{-1}$, which is due mainly to $v(\mathrm{CO})$ vibration [53], essentially disappears for all concentrations of $\mathrm{P} / \mathrm{CeO}_{2}$. At the same time, the intensity of the bands at 1188 and $1365 \mathrm{~cm}^{-1}$, which partially corresponds to the $\beta(\mathrm{COH})$ vibrations $[51,53]$, decreases significantly. Instead of a wide band with three peaks at 1242, $1255(\beta(\mathrm{COH})[51,53])$, and $1281 \mathrm{~cm}^{-1}(v(\mathrm{CO}))[51,53]$, for lower concentrations, one maximum was detected at $1261 \mathrm{~cm}^{-1}$, and only when the concentration of $P$ increases to $0.6 \mathrm{mmol} / \mathrm{g}$, a peak appears at $1273 \mathrm{~cm}^{-1}$. 
At the same time, all $\mathrm{P} / \mathrm{CeO}_{2}$ spectra contained a new band at $1297 \mathrm{~cm}^{-1}$, which may indicate the formation of a bond between pyrocatechol and $\mathrm{CeO}_{2}$. It is known that the new bands found in this area by the interaction of phenol and phenolic compounds with metal surfaces, as well as surfaces of oxides and hydroxides of metals [54-58], were signs of the formation of new bonds.

The binding of $\mathrm{P}$ to the oxide surface significantly affected the absorption of its aromatic ring, which manifested in the displacement of the absorption bands of $\mathrm{P}$ and changes in their intensity. In particular, for pure $\mathrm{P}$, the vibration band $v(\mathrm{CC})$ was registered at 1471, 1514, 1603, and $1620 \mathrm{~cm}^{-1}$ [53], while in the $\mathrm{P} / \mathrm{CeO}_{2}$ spectrum, the corresponding absorptions were registered at 1446,1483, and $1576 \mathrm{~cm}^{-1}$. Bands characteristic of pure $\mathrm{P}$ $\left(1471,1514,1603\right.$, and $\left.1620 \mathrm{~cm}^{-1}\right)$ also appeared in the spectra of $\mathrm{P} / \mathrm{CeO}_{2}$ samples with a $\mathrm{P}$ concentration above $0.6 \mathrm{mmol} / \mathrm{g}$ (Figure 1). This is probably because the amount of $\mathrm{P}$ exceeds the number of active centers of the $\mathrm{CeO}_{2}$ surface. The obtained results indicate the formation of chemisorbed pyrocatechol complexes on the $\mathrm{CeO}_{2}$ surface.

The $\mathrm{P} / \mathrm{CeO}_{2}$ spectrum (Figure 1) is similar to the IR spectra of pyrocatechol adsorbed on the nanosized $\mathrm{TiO}_{2}$ surface [51,59-61]. According to the results of quantum chemical calculations [61] and experimental data [51,56,60,61], this type of spectra of $\mathrm{P}$ adsorbed on $\mathrm{TiO}_{2}$, in which the bands $1250 \mathrm{~cm}^{-1}$ and $1475 \mathrm{~cm}^{-1}$ are the most intense, is more characteristic of complexes with a bidentate bridge structure. Since the most intense absorptions in the $\mathrm{P} / \mathrm{CeO}_{2}$ spectrum correspond to the bands 1263 and $1483 \mathrm{~cm}^{-1}$ (Figure 1), it is probable that the $\mathrm{P}$ complexes on the $\mathrm{CeO}_{2}$ surface also have a bidentate bridge structure (two oxide atoms of phenolic groups of $\mathrm{P}$ interact with two metal atoms).

\subsubsection{Guaiacol}

The FT-IR spectra obtained for pure $\mathrm{G}$ and immobilized on the surface of $\mathrm{CeO}_{2}$ are shown in Figure 2. The absence for $\mathrm{G} / \mathrm{CeO}_{2}$ of the absorption band at $1364 \mathrm{~cm}^{-1}$, which corresponds to $\beta(\mathrm{OH})$ [62] (Table 2), as well as the decrease in the intensity of absorption at $1261 \mathrm{~cm}^{-1}(v(\mathrm{CO})[62])$, indicates the participation of the $\mathrm{OH}$ group of $\mathrm{G}$ in the interaction with $\mathrm{CeO}_{2}$.

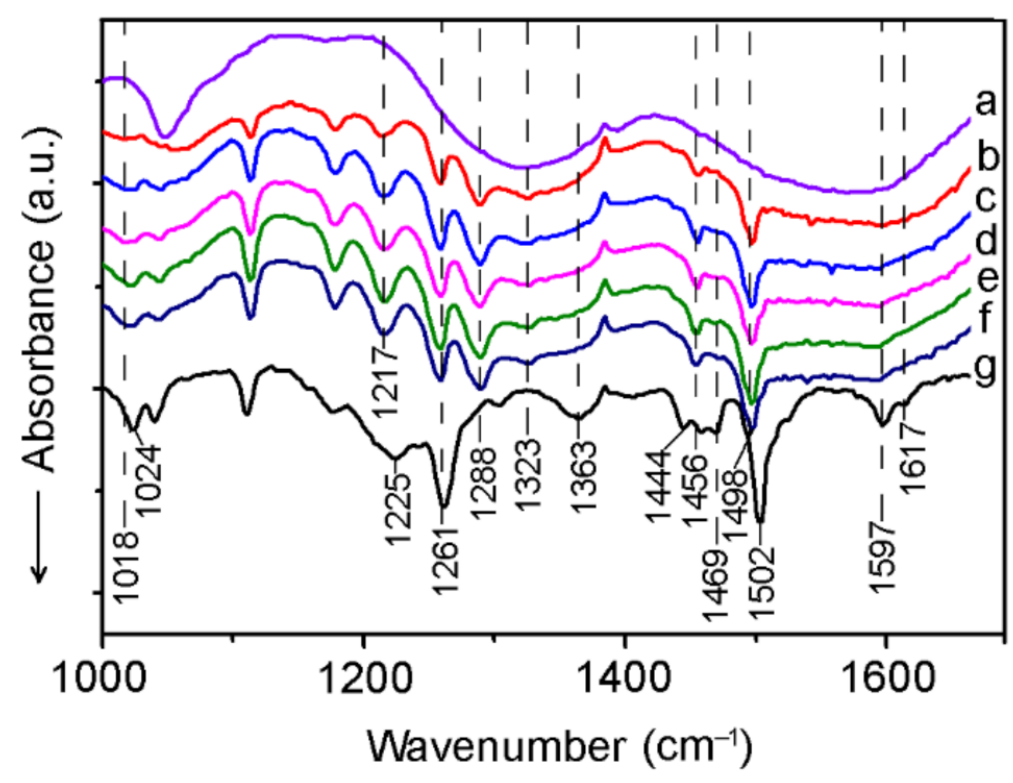

Figure 2. Fourier transform-infrared (FT-IR) spectra of pure $\mathrm{CeO}_{2}(\mathrm{a})$, samples of $\mathrm{G} / \mathrm{CeO}_{2}$ with different contents of $G(0.1: b ; 0.3: c ; 0.6: d ; 0.9:$ e; $1.2 \mathrm{mmol} / \mathrm{g}: \mathrm{f})$ and pure $G(\mathrm{~g})$. 
Table 2. Assignments of characteristic infrared bands of pure $\mathrm{G}$ and of $\mathrm{G} / \mathrm{CeO}_{2}(0.6 \mathrm{mmol} / \mathrm{g})$.

\begin{tabular}{cccc}
\hline \multirow{2}{*}{ Assignments } & \multicolumn{2}{c}{ Frequency $\mathbf{( \mathbf { c m } ^ { - \mathbf { 1 } } )}$} & Ref. \\
\cline { 2 - 3 } & $\mathbf{G}$ & $\mathbf{G} / \mathbf{C e O}_{\mathbf{2}}$ & {$[63]$} \\
$v_{\mathrm{s}}\left(\mathrm{COCH}_{3}\right)$ & 1024 & 1018 & {$[63]$} \\
$v_{\mathrm{as}}\left(\mathrm{COCH}_{3}\right)$ & 1225 & 1217 & {$[63]$} \\
$v(\mathrm{COH})$ & 1261 & 1261 & {$[63]$} \\
$v(\mathrm{CO})^{-}$ & - & 1288 & {$[63]$} \\
$v(\mathrm{CO})^{-}$ & - & 1323 & {$[63]$} \\
$\beta(\mathrm{COH})$ & 1363 & - & {$[63]$} \\
$\beta\left(\mathrm{CH}_{3}\right)$ & 1444 & - & {$[63]$} \\
$\beta\left(\mathrm{CH}_{3}\right)$ & 1469 & - & {$[63]$} \\
$v(\mathrm{CC})+\beta\left(\mathrm{CH}_{3}\right)$ & 1458 & 1456 & {$[63]$} \\
$v(\mathrm{CO})$ & 1508 & 1498 & {$[63]$} \\
$\nu(\mathrm{CC})$ & 1597 & 1595 & \\
$v(\mathrm{CC})$ & 1617 & - & \\
\hline
\end{tabular}

At the same time, for these samples, the bands of symmetric $\left(v_{\mathrm{s}}\right)$ and asymmetric $\left(v_{\text {as }}\right)$ valence vibrations of the $\mathrm{C}-\mathrm{O}-\mathrm{CH}_{3}$ groups, which were registered for guaiacol at 1024 and $1225 \mathrm{~cm}^{-1}$ [63], shifted to 1018 and $1217 \mathrm{~cm}^{-1}$, respectively. In addition, absorption bands in the range $1444-1469 \mathrm{~cm}^{-1}$, corresponding to the $\beta\left(\mathrm{CH}_{3}\right)$ vibrations $[62,63]$, were transformed. In particular, the peaks at 1444 and $1469 \mathrm{~cm}^{-1}$ disappeared, and the maximum at $1458 \mathrm{~cm}^{-1}$ shifted to $1456 \mathrm{~cm}^{-1}$. These changes indicate the interaction of the methoxyl groups of $\mathrm{G}$ with $\mathrm{CeO}_{2}$.

The new bands at 1288 and $1323 \mathrm{~cm}^{-1}$ in the spectra of $\mathrm{G} / \mathrm{CeO}_{2}$ samples were a sign of the formation of chemisorbed $\mathrm{G}$ complexes [62]. The absorptions for $v\left(\mathrm{CH}_{3}\right)$ at $2843 \mathrm{~cm}^{-1}$ partially remained in the spectra of $\mathrm{G} / \mathrm{CeO}_{2}$. Therefore, the interaction of the $\mathrm{COCH}_{3}$ group with the oxide surface probably occurred through an oxygen atom without cleavage of $\mathrm{CH}_{3}$. At the same time, it is possible that several methoxyl groups may have been freed.

Thus, the obtained data (Figure 2) indicate the formation of $G$ complexes on the nanoceria $\mathrm{CeO}_{2}$ bound to the oxide surface through the phenolic and methoxyl groups simultaneously, as well as separately through each of these groups.

In addition, the shift of the band of $C=C$ vibrations may also indicate the interaction of the aromatic ring $\mathrm{G}$ with the oxide surface [62]. Figure 2 shows that the $\mathrm{C}=\mathrm{C}$ band, which for pure $G$ is about $1502 \mathrm{~cm}^{-1}$, for the $\mathrm{G} / \mathrm{CeO}_{2}$ samples is shifted to $1498 \mathrm{~cm}^{-1}$. According to [62], such a shift may be a sign of the presence on the $\mathrm{CeO}_{2}$ surface of weakly bound $\mathrm{G}$ complexes, which occur due to the simultaneous formation of hydrogen bonds between the $\mathrm{CH}$-group of the aromatic ring and the surface hydroxyl as well as $\mathrm{OH}$ group of $G$ and the surface cerium atom.

\subsubsection{Vanillic Acid}

Figure 3 shows the spectra of pure VA immobilized on $\mathrm{CeO}_{2}$. The presence of different $\mathrm{COH}$ groups in the VA molecule complicates the interpretation of the obtained spectra. Literature data $[15,59,64,65]$ and our FT-IR spectroscopic studies of $\mathrm{P}, \mathrm{G}$, and carboxylic acids $[22,45,50]$ were used to analyze the IR spectra of pure VA and VA/CeO 2 . From the obtained spectra (Figure 3, Table 3), it was found that both the carboxyl group and the active groups of the aromatic ring of VA are involved in the interaction with $\mathrm{CeO}_{2}$. In particular, for $\mathrm{VA} / \mathrm{CeO}_{2}$ samples, a decrease in the intensity of bands at $1030 \mathrm{~cm}^{-1}$ $\left(v_{\mathrm{s}}\left(\mathrm{COCH}_{3}\right)\right), 1240 \mathrm{~cm}^{-1}\left(v_{\alpha \mathrm{s}}\left(\mathrm{COCH}_{3}\right)\right)[15,64]$ and at $1113,1188,1456$, and $1473 \mathrm{~cm}^{-1}$ $\left(\beta\left(\mathrm{CH}_{3}\right)\right)[15,65]$ was observed. This indicates the participation of the methoxyl group in the interaction with the oxide surface. 


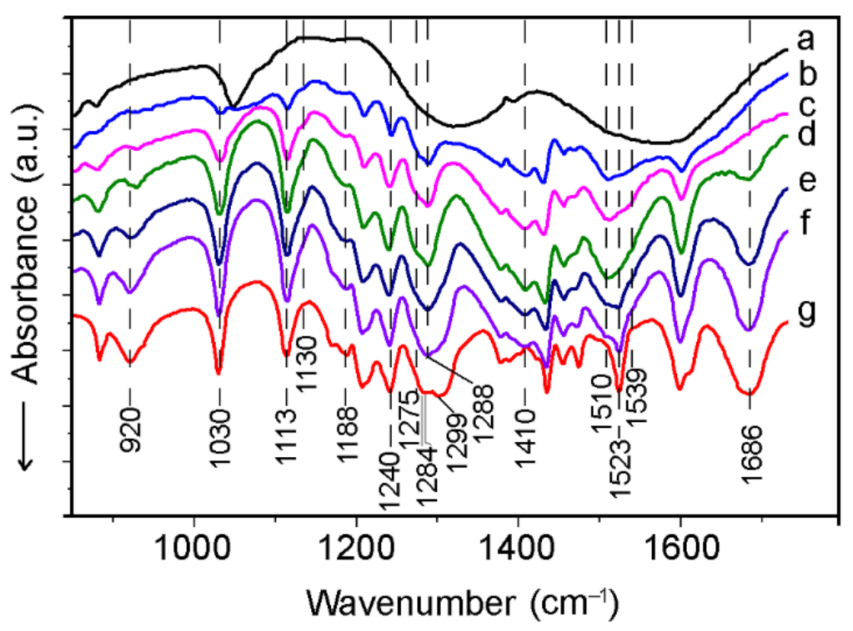

Figure 3. Fourier transform-infrared (FT-IR) spectra of pure $\mathrm{CeO}_{2}(\mathrm{a})$, samples of $\mathrm{VA} / \mathrm{CeO}_{2}$ with different contents of VA (0.1: b; 0.3: c; 0.6: d; 0.9: e; $1.2 \mathrm{mmol} / \mathrm{g}: \mathrm{f})$ and pure VA (g).

Table 3. Assignments of characteristic infrared bands of pure VA and of $\mathrm{VA} / \mathrm{CeO}_{2}(0.6 \mathrm{mmol} / \mathrm{g})$.

\begin{tabular}{|c|c|c|c|}
\hline \multirow{2}{*}{ Assignments } & \multicolumn{2}{|c|}{ Frequency $\left(\mathrm{cm}^{-1}\right)$} & \multirow{2}{*}{ Ref. } \\
\hline & VA & $\mathrm{VA} / \mathrm{CeO}_{2}$ & \\
\hline$\delta(\mathrm{COH})$ & 920 & $-*$ & [15] \\
\hline$v_{\mathrm{s}}\left(\mathrm{COCH}_{3}\right)$ & 1030 & 1018 & [15] \\
\hline$\beta\left(\mathrm{CH}_{3}\right)$ & 1113 & 1113 & [61] \\
\hline$\beta\left(\mathrm{CH}_{3}\right)$ & 1188 & 1188 & {$[15,65]$} \\
\hline$v_{\mathrm{as}}\left(\mathrm{COCH}_{3}\right)$ & 1240 & 1240 & [15] \\
\hline$v\left(\mathrm{CO}_{\mathrm{ap}}\right)$ & 1284 & 1288 & [15] \\
\hline$v(\mathrm{COH})+\beta(\mathrm{OH})$ & 1299 & - & [15] \\
\hline$v(\mathrm{CO})^{-}$ & - & 1275 & \\
\hline$\beta\left(\mathrm{CH}_{3}\right)$ & 1456 & 1456 & {$[15,65]$} \\
\hline$\beta\left(\mathrm{CH}_{3}\right)$ & 1473 & 1467 & {$[15,65]$} \\
\hline$v_{\mathrm{s}}\left(\mathrm{COO}^{-}\right)$ & - & 1410 & \\
\hline$v_{\mathrm{as}}\left(\mathrm{COO}^{-}\right)$ & - & 1539 & \\
\hline$v(\mathrm{C}=\mathrm{O})$ & 1686 & $-*$ & [15] \\
\hline
\end{tabular}

${ }^{*}$ for VA concentrations $0.1-0.3 \mathrm{mmol} / \mathrm{g}$.

A wide intense band, which in the spectra of pure acid has two maxima at $1284 \mathrm{~cm}^{-1}$ and $1299 \mathrm{~cm}^{-1}$, occurs mainly as a result of vibrations of carboxyl and aromatic $\mathrm{COH}$ groups $\left((\mathrm{COH})_{\mathrm{ar}}\right)$ of acid $[15,65]$. In the spectra of the $\mathrm{VA} / \mathrm{CeO}_{2}$ samples, it undergoes significant transformations; instead of two maxima, a peak appears at $1288 \mathrm{~cm}^{-1}$ and a shoulder in the $1275 \mathrm{~cm}^{-1}$ region. From this, we can conclude that both the carboxyl and phenolic groups can be involved in binding to the surface of $\mathrm{CeO}_{2}$.

According to studies of complexes of ferulic and caffeic acids with the metal ions $\left(\mathrm{Cu}^{2+}, \mathrm{Al}^{3+}, \mathrm{Na}^{+}\right) \mathrm{CuCl}_{2}, \mathrm{AlCl}_{3}$, and $\mathrm{Na}$ [66], new absorption bands associated with the formation of bonds between aromatic ligands of these acids and metal ions can appear in the FT-IR spectra in the region from 1090 to $1300 \mathrm{~cm}^{-1}$. Their position depends on the type of metal and the reagent ratio [66]. The high reactivity of phenolic $\mathrm{OH}$ groups of a number of carboxylic aromatic acids (vanillic, gallic, and caffeic) in interaction with cerium oxide was also recorded in [67] by UV-Vis spectroscopy.

A number of signs indicating the formation of carboxylate complexes were detected in the $\mathrm{VA} / \mathrm{CeO}_{2}$ spectra. In particular, the absorption at $1686 \mathrm{~cm}^{-1}(v(\mathrm{C}=\mathrm{O}))$ and $920 \mathrm{~cm}^{-1}$ $(\delta(\mathrm{COH}))[15])$ disappeared for concentrations of $0.1-0.3 \mathrm{mmol} / \mathrm{g}$, and for higher concentrations the intensity of these bands were smaller compared to pure VA. At the same time, the broad bands appeared at $1410 \mathrm{~cm}^{-1}\left(v_{\mathrm{s}}\left(\mathrm{COO}^{-}\right)\right)$and $1539 \mathrm{~cm}^{-1}\left(v_{\mathrm{as}}\left(\mathrm{COO}^{-}\right)\right.$. The presence in this part of the spectrum of absorption bands $v(C C)\left(\right.$ at $1523 \mathrm{~cm}^{-1}$-for 
pure VA) prevented an accurately identification of the bands at $\sim 1510 \mathrm{~cm}^{-1}$ for $\mathrm{VA} / \mathrm{CeO}_{2}$ samples. It may correspond to both $v_{\mathrm{as}}\left(\mathrm{COO}^{-}\right)$and $v(\mathrm{CC})$. The difference, $\Delta v=v_{\mathrm{as}}(\mathrm{COO})$ $-v_{\mathrm{S}}\left(\mathrm{COO}^{-}\right)$, was used as a criterion to establish the coordination of the $\mathrm{COO}^{-}$group to the metal [68] and oxide surfaces [22,45,59,69-71]. The value of $\Delta v$ for $\mathrm{VA} / \mathrm{CeO}_{2}$ was $129 \mathrm{~cm}^{-1}$, which corresponded to the bidentate VA complexes with a bridge structure formed on the nanoceria surface.

\subsubsection{Ferulic Acid}

FA has a more complex structure compared to VA because it has a group $\mathrm{C}=\mathrm{C}$ in the aliphatic part of the acid. This is manifested in its vibrational spectrum (Figure 4, Table 4). The interaction of FA with the oxide surface caused a number of changes in the spectra of FA/ $\mathrm{CeO}_{2}$ (Figure 4). Bands $1036 \mathrm{~cm}^{-1}\left(v_{\mathrm{s}}\left(\mathrm{C}-\mathrm{O}-\mathrm{CH}_{3}\right)\right)$ and $1205 \mathrm{~cm}^{-1}\left(v_{\mathrm{as}}(\mathrm{C}-\right.$ $\left.\left.\mathrm{O}-\mathrm{CH}_{3}\right)\right)[72,73]$ for $\mathrm{FA} / \mathrm{CeO}_{2}$ were shifted to $1034 \mathrm{~cm}^{-1}$ and $1211 \mathrm{~cm}^{-1}$, respectively. In addition, bands at 1115 and $1178 \mathrm{~cm}^{-1}$ disappeared in the $\mathrm{FA} / \mathrm{CeO}_{2}$ spectra, which was most likely associated with $\beta\left(\mathrm{CH}_{3}\right)$ vibrations [72], and a new band appeared at $1124 \mathrm{~cm}^{-1}$. The intensity of the band $1466 \mathrm{~cm}^{-1}\left(\beta\left(\mathrm{CH}_{3}\right)\right)[64,72]$ significantly decreased (Figure 4). This indicates the participation of the methoxyl group in the interaction with the nanoceria surface.

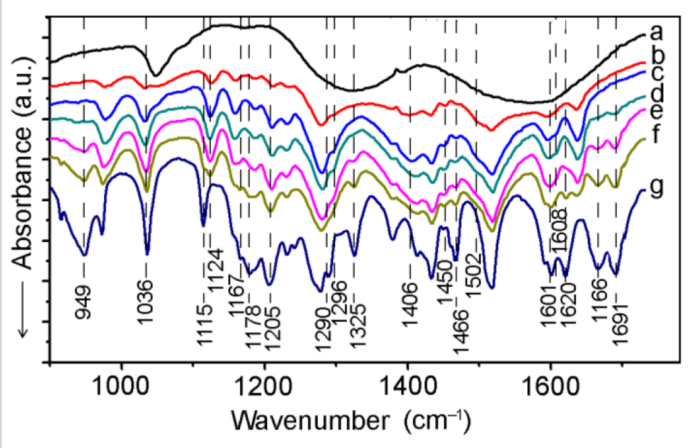

Figure 4. Fourier transform-infrared spectra of pure $\mathrm{CeO}_{2}(\mathrm{a})$, samples of $\mathrm{FA} / \mathrm{CeO}_{2}$ with different contents of FA (0.1: b; 0.3: c; 0.6: d; 0.9: e; $1.2 \mathrm{mmol} / \mathrm{g}: \mathrm{f})$ and pure FA (g).

Table 4. Assignments of characteristic infrared bands of pure FA and of $\mathrm{FA} / \mathrm{CeO}_{2}(0.6 \mathrm{mmol} / \mathrm{g})$.

\begin{tabular}{|c|c|c|c|}
\hline \multirow{2}{*}{ Assignments } & \multicolumn{2}{|c|}{ Frequency $\left(\mathrm{cm}^{-1}\right)$} & \multirow{2}{*}{ Ref. } \\
\hline & FA & $\mathrm{FA} / \mathrm{CeO}_{2}$ & \\
\hline$\delta(\mathrm{COH})$ & 920 & - & {$[64,74]$} \\
\hline$v_{\mathrm{s}}\left(\mathrm{COCH}_{3}\right)$ & 1036 & 1034 & {$[72,73]$} \\
\hline$\beta\left(\mathrm{CH}_{3}\right)$ & 1115 & 1124 & {$[73]$} \\
\hline$\beta(\mathrm{OH})_{\mathrm{ap}}$ & 1167 & - & [73] \\
\hline$\beta(\mathrm{OH})_{\mathrm{ap}}$ & 1178 & - & [73] \\
\hline$v_{\mathrm{as}}\left(\mathrm{COCH}_{3}\right)$ & 1205 & 1211 & {$[72,73]$} \\
\hline$v(\mathrm{CO})_{\mathrm{ap}}$ & 1290 & - & {$[72,73]$} \\
\hline$v(\mathrm{CO})_{\mathrm{ap}}^{-}$ & - & 1296 & \\
\hline$v(\mathrm{CO})$ & - & 1405 & \\
\hline$v_{\mathrm{s}}\left(\mathrm{COO}^{-}\right)$ & & 1450 & \\
\hline$\beta\left(\mathrm{CH}_{3}\right)$ & 1466 & 1468 & {$[64,72]$} \\
\hline$v_{\mathrm{as}}\left(\mathrm{COO}^{-}\right)$ & - & 1502 & \\
\hline$v(C C)_{a p}$ & 1601 & 1601 & [72] \\
\hline$v(\mathrm{C}=\mathrm{O})$ & - & 1608 & \\
\hline$v(\mathrm{C}=\mathrm{C})$ & 1620 & 1637 & [72] \\
\hline$v_{\mathrm{s}}\left(\mathrm{COO}^{-}\right)$ & 1666 & - & [72] \\
\hline$v_{\mathrm{s}}\left(\mathrm{COO}^{-}\right)$ & 1691 & - & [72] \\
\hline
\end{tabular}


The absorption ratios at $1115 \mathrm{~cm}^{-1}$ for pure FA in the literature data differ between $\left(\beta\left(\mathrm{CH}_{3}\right)-[72]\right)$ and $(\beta(\mathrm{CH})-[74])$, as well as the absorption ratios of bands at $1113 \mathrm{~cm}^{-1}$ for VA $\left(\beta\left(\mathrm{CH}_{3}\right)-[65]\right)$ and $(\beta(\mathrm{CH})-[15])$. However, these bands all corresponded to $\left(\beta\left(\mathrm{CH}_{3}\right)\right)$, while the new bands, which appeared at $1124 \mathrm{~cm}^{-1}$ for $\mathrm{FA} / \mathrm{CeO}_{2}$ and $1130 \mathrm{~cm}^{-1}$-for $\mathrm{VA} / \mathrm{CeO}_{2}$, corresponded to $\beta\left(\mathrm{CH}_{3}\right)$ vibrations of methoxyl groups involved in the interaction with the surface.

The interaction of the aromatic $\mathrm{OH}$ group of $\mathrm{FA}$ with $\mathrm{CeO}_{2}$ can be evidenced by the absence of bands in the spectra of the FA $/ \mathrm{CeO}_{2}$ samples at $1167 \mathrm{~cm}^{-1} \beta(\mathrm{OH})_{\mathrm{ar}}$ [72] and $1290 \mathrm{~cm}^{-1}\left(v(\mathrm{CO})_{\mathrm{ar}}\right)$ [72], and the appearance of absorption at $1296 \mathrm{~cm}^{-1}(0.1-0.6 \mathrm{mmol} / \mathrm{g})$. Thus, we can discuss the interaction of FA with the surface of $\mathrm{CeO}_{2}$ through both methoxyl and phenolic groups.

The formation of carboxylate complexes of FA on the cerium oxide surface was also detected by the FT-IR spectra of FA/ $\mathrm{CeO}_{2}$ samples (Figure 4 ). The appearance of bands at $1405 \mathrm{~cm}^{-1}(\mathrm{CO})$ and $1608 \mathrm{~cm}^{-1}(\mathrm{C}=\mathrm{O})$ may be associated with the formation of monodentate carboxylate complexes $\left(\Delta v=v(C=O)-v(C-O)=203 \mathrm{~cm}^{-1}\right)$. The band $1608 \mathrm{~cm}^{-1}$ overlapped with the absorption of the aromatic ring vibration $\left(1601 \mathrm{~cm}^{-1}\right)$. The new bands at $1450 \mathrm{~cm}^{-1}\left(v_{\mathrm{as}}\left(\mathrm{COO}^{-}\right)\right)$and $1502 \mathrm{~cm}^{-1}\left(v_{\mathrm{as}}\left(\mathrm{COO}^{-}\right)\right)$corresponded to the bidentate chelate complexes, since $\Delta v=52 \mathrm{~cm}^{-1}$.

The $\mathrm{C}=\mathrm{O}$ vibrations at 1666 and $1691 \mathrm{~cm}^{-1}$ as well as $\beta(\mathrm{COH})$ at $1325 \mathrm{~cm}^{-1}$ and $\delta(\mathrm{COH})$ at $949 \mathrm{~cm}^{-1}\left([64,74]\right.$ in the spectra of $\mathrm{FA} / \mathrm{CeO}_{2}(0.1-0.6 \mathrm{mmol} / \mathrm{g})$ disappeared. The appearance of these and other bands of pure acid in the $\mathrm{FA} / \mathrm{CeO}_{2}$ spectra $(0.9-1.2 \mathrm{mmol} / \mathrm{g})$ was due to the formation of intermolecular acid associates. This was confirmed by the presence of absorptions in the region of $2400 \mathrm{~cm}^{-1}$, which correspond to $v(\mathrm{OH})$ of dimers [64]. FA associates can form on the surface when the number of FA molecules exceeds the available active centers of the oxide surface.

A significant shift up to $1637 \mathrm{~cm}^{-1}$ was observed for the absorption band $v(C=C)$ for the $\mathrm{FA} / \mathrm{CeO}_{2}$ samples. Such a type of shift was also found in the interaction of FA with metals $[74,75]$.

\subsection{Thermal Transformations of Model Lignin Compounds on the Surface of $\mathrm{CeO}_{2}$}

\subsubsection{Pyrocatechol}

The study of thermal transformations of $\mathrm{P} / \mathrm{CeO}_{2}$ samples by the TPD MS method is presented in Figure 5. According to thermograms and the P/T-curve (Figure 5), the thermal decomposition of $\mathrm{P} / \mathrm{CeO}_{2}$ occurred in several stages at the range of $50-750{ }^{\circ} \mathrm{C}$. At the same time, no desorption of pyrocatechol in molecular form (M.r. $=110 \mathrm{Da}, \mathrm{m} / z$ 110) was observed over the entire temperature range studied. This indicates that pyrocatechol binds to the surface of nanoceria, and its pyrolysis occurs due to the transformation of surface complexes. This is confirmed by the data of IR spectroscopy, according to which changes in the absorption of $\mathrm{COH}$ groups and the appearance of a new band at $1297 \mathrm{~cm}^{-1}$ indicate chemisorption of pyrocatechol.

In this case, one feature was observed: the peaks at a temperature of about $120{ }^{\circ} \mathrm{C}$ on the TPD curves for aliphatic series ions $m / z$ 99, 85, 71, 57, and 43. According to [76], such a set of ions is characteristic of aliphatic compounds, namely, alkyl derivatives, alicyclic alcohols $\left(m / z 99\left(\mathrm{C}_{6} \mathrm{H}_{11} \mathrm{O}\right), m / z 85\left(\mathrm{C}_{6} \mathrm{H}_{12}\right), m / z 71\left(\mathrm{C}_{5} \mathrm{H}_{11}\right), m / z 57\left(\mathrm{C}_{4} \mathrm{H}_{9}\right)\right.$, and $m / z 43$ $\left.\left(\mathrm{C}_{3} \mathrm{H}_{7}\right)\right)$. The formation of aliphatic products can result from the decomposition of phenolate complexes of pyrocatechol. It is known that the Ar-OH bond is one of the strongest types of C-O bonds, for example, for guaiacol and other phenol derivatives [35]. It is believed that, before breaking, this bond must first be weakened by hydrogenating the aromatic ring $[43,77,78]$. According to [43], deoxygenation in the presence of the catalysts $\mathrm{CeO}_{2}$ and $\mathrm{CeO}_{2}-\mathrm{ZrO}_{2}$ occurs more easily from the saturated cycle than from the unsaturated cycle. This is due to the dissociation energy of the $\mathrm{CO}$ bond in alcohols, which decreases in the following order: aromatic alcohol $(469 \mathrm{~kJ} / \mathrm{mol})$, secondary alcohol $(385 \mathrm{~kJ} / \mathrm{mol})$, primary alcohol $(383 \mathrm{~kJ} / \mathrm{mol})$, tertiary alcohol $(379 \mathrm{~kJ} / \mathrm{mol})$ [43]. We do not rule out the possibility of such a process on the surface of $\mathrm{CeO}_{2}$, because during the study, we recorded 
an intense signal of hydrogen evolution $(m / z 3)$ (Figure 5B). The formation of aliphatic products was likely due to complex redox processes on the surface of nanoceria. However, the intensity of these processes was low. The main processes were of deep destruction of pyrocatechol. This conclusion can be made by comparing the intensities of TPD peaks of the aliphatic series with TPD peaks, which characterize the processes of dehydration $(\mathrm{m} / \mathrm{z}$ 18 ), decarboxylation $(m / z 44)$, and desorption of $\mathrm{CO}$ and $\mathrm{C}_{2} \mathrm{H}_{4}(m / z 28)$ (Figure $\left.5 \mathrm{C}, \mathrm{D}\right)$. The strong influence of the interactions with catalyst surface on the structure of the pyrocatechol molecule was also indicated by the obtained IR spectra. Figure 1 shows that significant changes occurred not only in the absorption of $\mathrm{COH}$ groups, through which the interaction occurs, but also in the absorption of the aromatic ring. In particular, the absorption at $1471 \mathrm{~cm}^{-1}$ shifted by $12 \mathrm{~cm}^{-1}$ to the high-frequency region, and the absorption at 1603 and $1620 \mathrm{~cm}^{-1}$ was almost invisible for small concentrations $(0.1-0.3 \mathrm{mmol} / \mathrm{g})$.
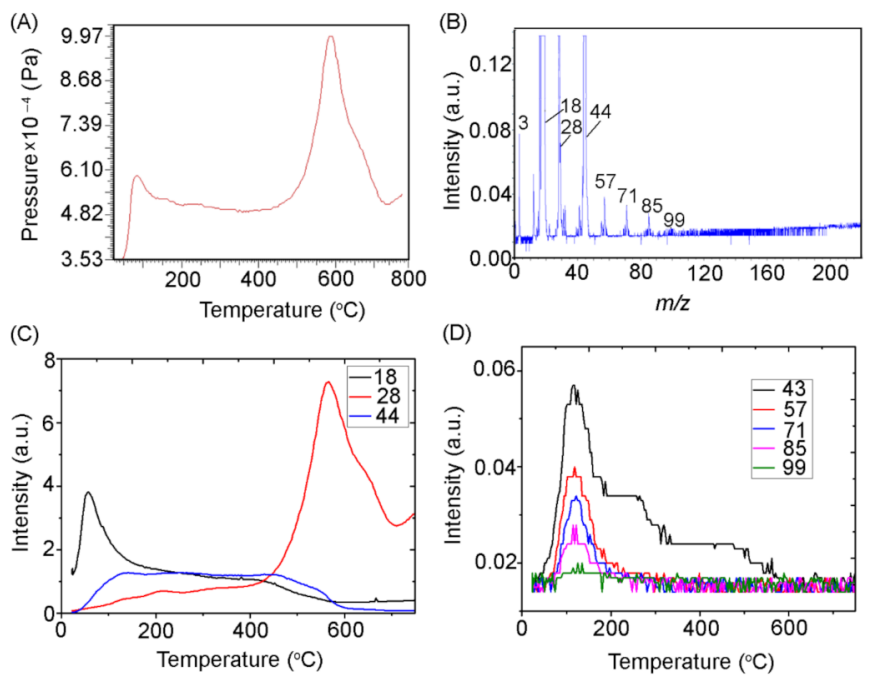

Figure 5. Thermal decomposition of $\mathrm{P} / \mathrm{CeO}_{2}(0.6 \mathrm{mmol} / \mathrm{g})$; vapor pressure measured as a function of temperature for the $\mathrm{FA} / \mathrm{Al}_{2} \mathrm{O}_{3}$ sample (A); mass spectra at $120^{\circ} \mathrm{C}(\mathbf{B})$; TPD curves for ions with $m / z 18,28$, and 44 (C); for ions with $m / z 43,57,71,85$, and 99 (D).

Figure 6 and Table 5 show the results of a DTG/DTA/TG study of $\mathrm{CeO}_{2}$ and $\mathrm{P} / \mathrm{CeO}_{2}$ samples. The main weight loss of the $\mathrm{CeO}_{2}$ sample is recorded in the temperature range 20-200 ${ }^{\circ} \mathrm{C}$, which was probably associated with the desorption of water from the oxide surface. The decomposition of the $\mathrm{G} / \mathrm{CeO}_{2}$ sample, according to the DTG curve (Figure $6 \mathrm{~A}$ ), proceeded in two stages: $100-150{ }^{\circ} \mathrm{C}$ and $150-430{ }^{\circ} \mathrm{C}$. All stages were exothermic. The main weight loss occurred in the second stage.
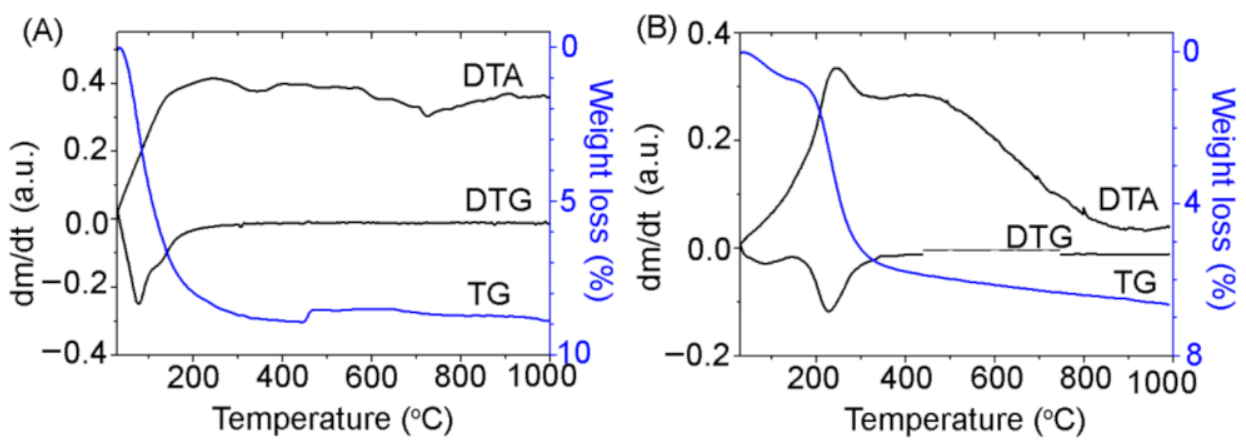

Figure 6. Differential thermal analysis (DTA), differential thermogravimetric analysis (DTG), and thermogravimetric (TG) curves for $\mathrm{CeO}_{2}(\mathbf{A})$ and $\mathrm{P} / \mathrm{CeO}_{2}(0.6 \mathrm{mmol} / \mathrm{g})(\mathbf{B})$. 
Table 5. Pyrolysis yields for TGA pyrolysis of $\mathrm{P} / \mathrm{CeO} 2(0.6 \mathrm{mmol} / \mathrm{g})$.

\begin{tabular}{ccccc}
\hline Sample & Stage & $\mathbf{T}_{\max }\left({ }^{\circ} \mathbf{C}\right)$ & Volatiles (\%) & Char (\%) \\
\hline & I & 85 & 8.4 & \\
$\mathrm{P} / \mathrm{CeO}_{2}$ & II & 224 & 72.3 & 19.3 \\
& $\Sigma(\mathrm{I}+\mathrm{II})$ & & 80.7 & \\
\hline
\end{tabular}

\subsubsection{Guaiacol}

Pyrolysis of guaiacol on the surface of nanoceria proceeded similarly to pyrolysis of pyrocatechol (Figure 7). Namely, there was no desorption of guaiacol in molecular form (M.r. $=124 \mathrm{Da}, m / z 124)$; the formation of aliphatic products $(m / z 99,85,71,57,43)$ occurred in the same temperature range. Consequently, their formation was probably the result of transformations of similar surface complexes $\mathrm{P}$ and $\mathrm{G}$ on the nanoceria surface. It could also be phenolate complexes, which were confirmed above using IR spectroscopy.
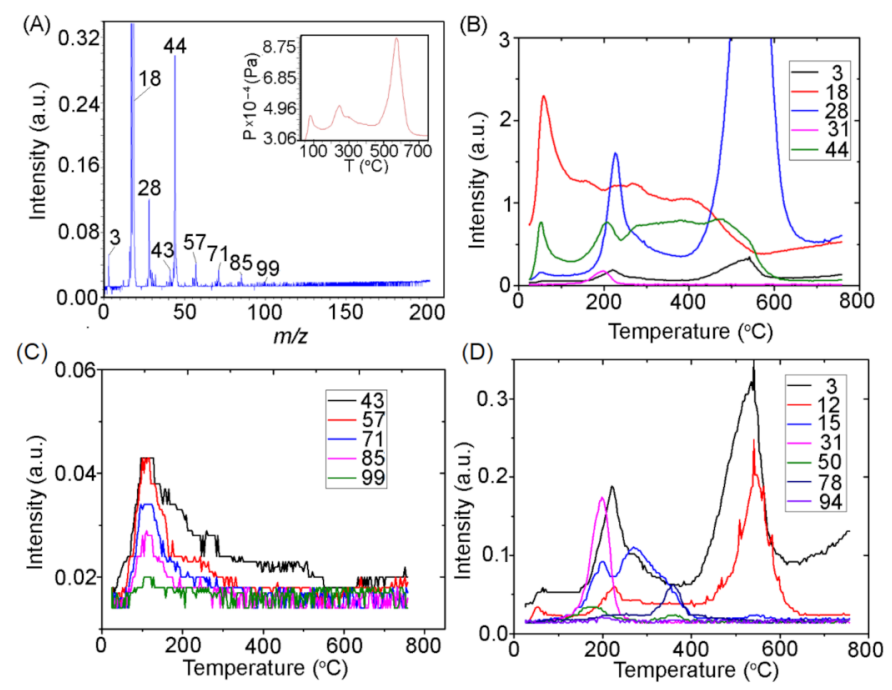

Figure 7. Thermal decomposition of $\mathrm{G} / \mathrm{CeO}_{2}(0.6 \mathrm{mmol} / \mathrm{g})$; mass spectra at $120^{\circ} \mathrm{C}$ and vapor pressure measured as a function of temperature for the $\mathrm{G} / \mathrm{CeO}_{2}$ sample (A); TPD curves for ions with $m / z 3,18,28,31$, and 44 (B); for ions with $m / z 43,57,71,85$, and 99 (C); for ions with $m / z 3,12$, $15,31,50,78$, and $94(\mathbf{D})$.

The presence of peaks on the TPD curves for ions with $m / z 31,32\left(\mathrm{CH}_{3} \mathrm{OH}\right)$ and $m / z 94(\mathrm{PhOH})$ indicates the presence of an additional stage of pyrolysis, probably as a result of thermal transformations of G-complexes bound to the surface through the methoxyl group, the formation of which was evidenced by a number of changes recorded in the absorption of the methoxyl group during the study of these samples by the FT-IR spectroscopy (Figure 2 and Table 2).

A peak at $\sim 358^{\circ} \mathrm{C}$ on the TPD curve for the ion with $m / z 78$ (benzene) was recorded as well as a minor release of the product with $m / z 94$ (hydroxybenzene). The intensity of the latter was low. These peaks could be associated with the decomposition of G-complexes, which were formed due to the interaction of both active groups of the aromatic ring with two active centers of the cerium oxide surface. The existence of bidentate structures on the oxide surface was evidenced by the disappearance of absorption at $1363 \mathrm{~cm}^{-1}(\beta(\mathrm{COH}))$ and the appearance of new bands at 1288 and $1323 \mathrm{~cm}^{-1}$ in the IR spectra of the $\mathrm{G} / \mathrm{CeO}_{2}$ samples (Figure 2). The work [35] confirms the possibility of forming such G-complexes on the $\mathrm{CeO}_{2}$ surface. It was found that the hydrodeoxygenation of guaiacol over $\mathrm{CeO}_{2}-\mathrm{ZrO}_{2}$ catalysts required two oxygen vacancies [35].

Intense peaks on the TPD curves of ions with $m / z 28\left(\mathrm{C}_{2} \mathrm{H}_{4}\right), m / z 14\left(\mathrm{CH}_{2}\right), m / z 12$ (C), and $m / z 3(\mathrm{H})$ at $225^{\circ} \mathrm{C}$ were observed during thermal decomposition of the $\mathrm{G} / \mathrm{CeO}_{2}$ samples (Figure 7B). The presence of these peaks indicates intense desorption of ethylene 
$\left(\mathrm{C}_{2} \mathrm{H}_{4}\right.$, M.r. $\left.=28, m / z 28,14,12\right)$, that can serve as confirmation of the alkylation processes of the nanoceria surface, which occurs during the pyrolysis of G. The data presented in [35] confirm the possibility of alkylation of the oxide surface during pyrolysis of $\mathrm{G}$.

The DTG/DTA/TG study results of the $\mathrm{G} / \mathrm{CeO}_{2}$ pyrolysis are presented in Figure 8 . The thermal decomposition of the sample occurred up to $400{ }^{\circ} \mathrm{C}$. On the DTG curve, we can distinguish two stages of weight loss for the $\mathrm{G} / \mathrm{CeO}_{2}$ sample. The first stage corresponded to $\mathrm{T}_{\max } \sim 100{ }^{\circ} \mathrm{C}$, the second to $\mathrm{T}_{\max } \sim 180^{\circ} \mathrm{C}$. All stages were exothermic. The maximum weight loss occurred in the second stage at $\sim 180^{\circ} \mathrm{C}$ (Table 6).

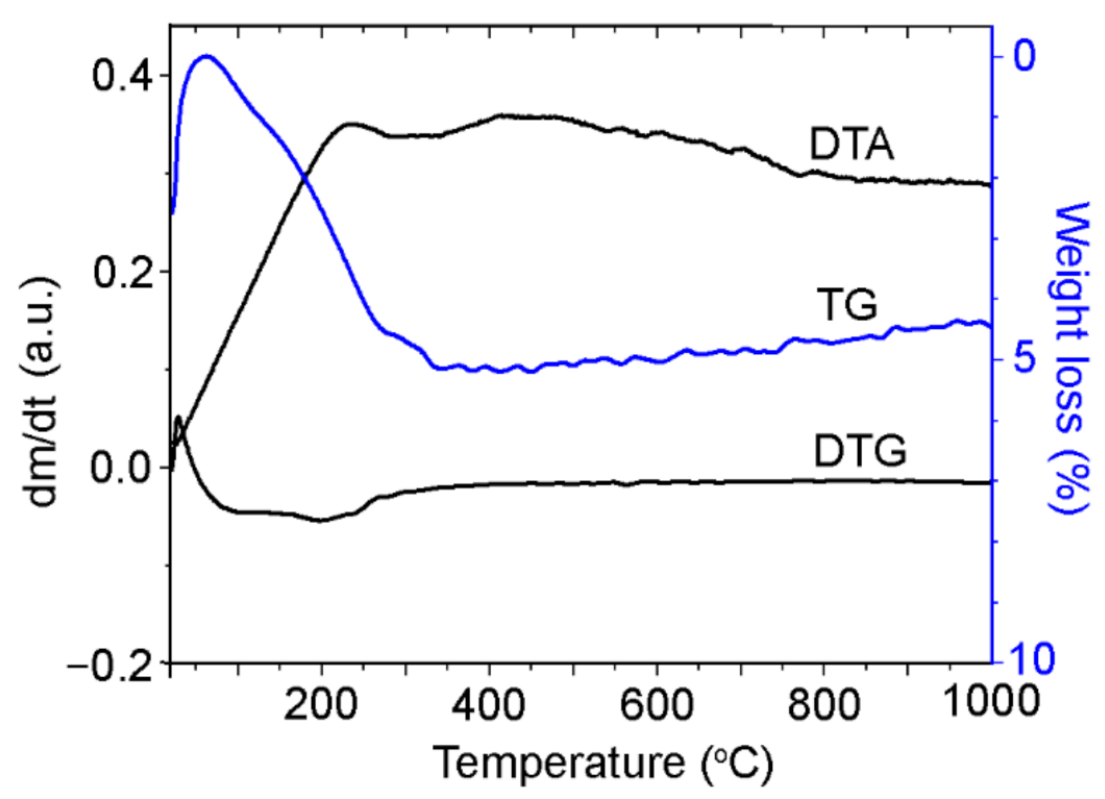

Figure 8. Differential thermal analysis (DTA), differential thermogravimetric analysis (DTG), and thermogravimetric (TG) curves for $\mathrm{G} / \mathrm{CeO}_{2}(0.6 \mathrm{mmol} / \mathrm{g})$.

Table 6. Pyrolysis yields for TGA pyrolysis of $\mathrm{G} / \mathrm{CeO}_{2}(0.6 \mathrm{mmol} / \mathrm{g})$.

\begin{tabular}{ccccc}
\hline Sample & Stage & $\mathbf{T}_{\max }\left({ }^{\circ} \mathbf{C}\right)$ & Volatiles (\%) & Char (\%) \\
\hline \multirow{2}{*}{$\mathrm{G} / \mathrm{CeO}_{2}$} & I & 100 & 20.3 & \\
& II & 180 & 49.3 & 30.4 \\
\hline
\end{tabular}

Analysis of TPD MS and DTG data of the $\mathrm{G} / \mathrm{CeO}_{2}$ samples (Table 6 and Figures 7 and 8) may indicate that the greatest weight loss occurs due to the decomposition of the Gcomplexes formed through the methoxyl group.

\subsubsection{Vanillic Acid}

The TPD MS study results of the VA/ $\mathrm{CeO}_{2}$ sample are presented in Figure 9. The decomposition interval of VA on the $\mathrm{CeO}_{2}$ surface was $100-750{ }^{\circ} \mathrm{C}$ (Figure 9). According to thermograms and the $\mathrm{P} / \mathrm{T}$-curve (Figure $9 \mathrm{C}, \mathrm{D}$ ), the pyrolysis of VA on the $\mathrm{CeO}_{2}$ surface occurred in several main stages: $130,270,370,550$, and $650{ }^{\circ} \mathrm{C}$. 

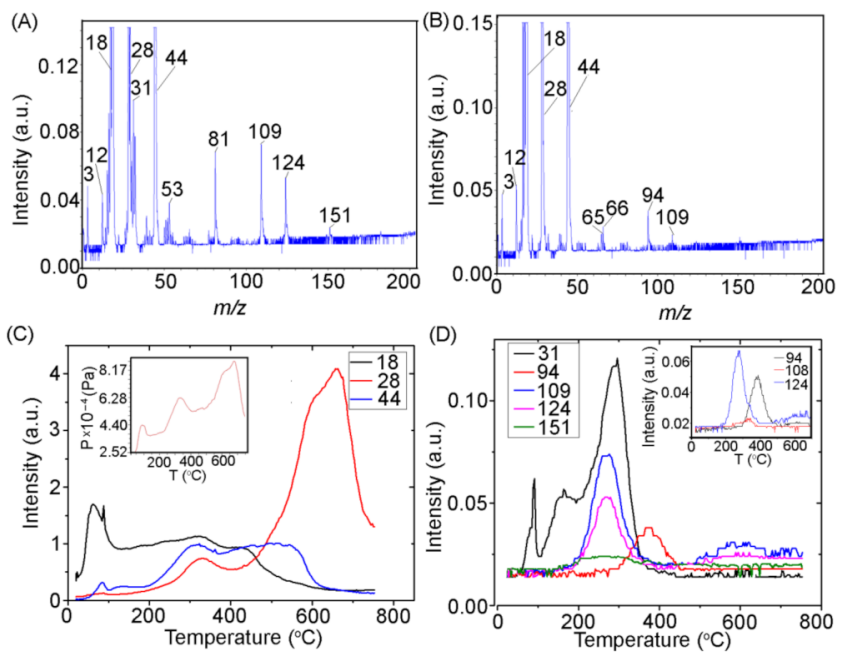

Figure 9. Thermal decomposition of $\mathrm{VA} / \mathrm{CeO}_{2}(0.6 \mathrm{mmol} / \mathrm{g})$; mass spectra at $270{ }^{\circ} \mathrm{C}(\mathrm{A})$ and $410{ }^{\circ} \mathrm{C}$ (B); TPD-curves for ions with $m / z 18,24,44$, and vapor pressure measured as a function of temperature for the $\mathrm{VA} / \mathrm{CeO}_{2}$ sample (C); TPD-curves for ions with $m / z 31,94,109,124,151$, and 182 and for ions with $m / z 94,108$, and 124 (D).

The low-intense peak of decarboxylation $\left(\mathrm{m} / \mathrm{z} 44, \mathrm{~T}_{\max } \sim 130^{\circ} \mathrm{C}\right)$ probably corresponds to the decomposition of associates of VA, which formed on the oxide surface, as was recorded during the pyrolysis of caffeic acid on $\mathrm{CeO}_{2}$ [79] (Figure 9C). The formation of such associates in the $\mathrm{VA} / \mathrm{CeO}_{2}$ sample was confirmed by the presence in their IR spectra of bands at $1686 \mathrm{~cm}^{-1}(v(\mathrm{C}=\mathrm{O}))$ and $920 \mathrm{~cm}^{-1}(\delta(\mathrm{COH}))$ (Figure 3$)$ as well as in the region $2400-2700 \mathrm{~cm}^{-1}$, which belongs to pure acid. Intense release of guaiacol (M.r. $=124 \mathrm{Da}, \mathrm{m} / z 124, \mathrm{~T}_{\max } \sim 270{ }^{\circ} \mathrm{C}$ ) can be a consequence of the decarboxylation of VA molecules bound to the oxide surface through the carboxyl group (Scheme 1), similar to the decomposition of the caffeic acid carboxylate complexes on the $\mathrm{CeO}_{2}$ surface [79] and on the $\mathrm{SiO}_{2}$ surface [80]. The involvement of the carboxyl group of $\mathrm{VA}$ in the interaction with the oxide was confirmed by the appearance of $v\left(\mathrm{COO}^{-}\right)$bands $\left(1410,1539 \mathrm{~cm}^{-1}\right)$ in the IR spectra (Figure 3$)$. The second low-intensity peak was observed for guaiacol $(\mathrm{m} / z$ 124) ( $\mathrm{T}_{\max } \sim 330{ }^{\circ} \mathrm{C}$, Figure $9 \mathrm{D}$ ), which can be formed by pyrolysis of VA molecules bound to the oxide through $\mathrm{OH}_{\mathrm{ar}}$. The possibility of such a bond is indicated by the transformation of the $1284 \mathrm{~cm}^{-1}$ band, which corresponds to the vibrations of the $\mathrm{CO}_{\text {ap }}$ group (Figure 3). Along with guaiacol at about $330{ }^{\circ} \mathrm{C}$, the release of a product with $\mathrm{m} / z 108$ was recorded, which can be identified as anisole. It can also be a conversion product of a VA complex linked through $\mathrm{OH}_{\mathrm{ar}}$. However, since the $\mathrm{C}-\mathrm{OH}$ bond was strong [14], and the probability of breaking this bond is small, a product with $m / z 108$ may correspond to cresol.

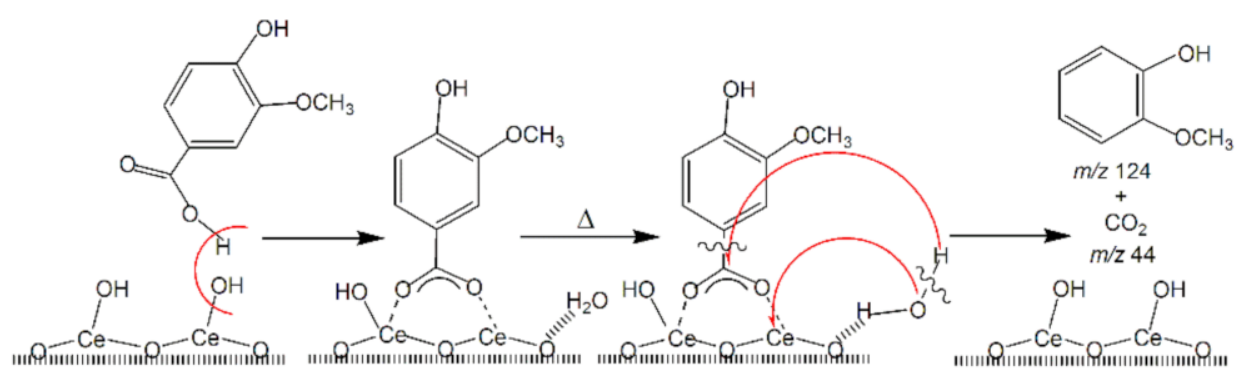

Scheme 1. The decarboxylation of VA molecules bound to the oxide surface through the carboxyl group.

It is known that phenol can be transalkylated to various cresol isomers [81]. This reaction requires Lewis acid sites, which promote the formation of a methyl cation as an 
intermediate in the alkylation reaction [82]. In addition, it is known [81] that $\mathrm{CeO}_{2}$ is a good catalyst for ortho-methylation of phenol with methanol. Therefore, it is likely that surface methoxy groups, which are formed by the decomposition of VA complexes associated with the methoxyl group, can react with oxygen vacancies, turning into surface methyl groups involved in the transalkylation reaction [35]. The presence of the methoxyl and methyl groups linked to the surface was confirmed by peaks on the TPD curves of the ions with $m / z 32,31$, and 15 . These peaks at $\mathrm{T}_{\max } \approx 294^{\circ} \mathrm{C}$ are probably related to desorption methanol $\left(\mathrm{CH}_{3} \mathrm{OH}\right.$, M.r. $=32 \mathrm{Da}, m / z$ 32, 31) [76] (Figure 9D).

In our opinion, the release of hydroxybenzene $\left(\mathrm{T}_{\max } \sim 380^{\circ} \mathrm{C}\right.$, Figure $\left.9 \mathrm{D}\right)$ can also result from the transformation of the phenolic complex linked through both active groups of the aromatic ring (Scheme 2). Such a decomposition mechanism was observed for similar caffeic acid complexes on the surfaces of $\mathrm{CeO}_{2}$ and $\mathrm{SiO}_{2}[79,80]$.

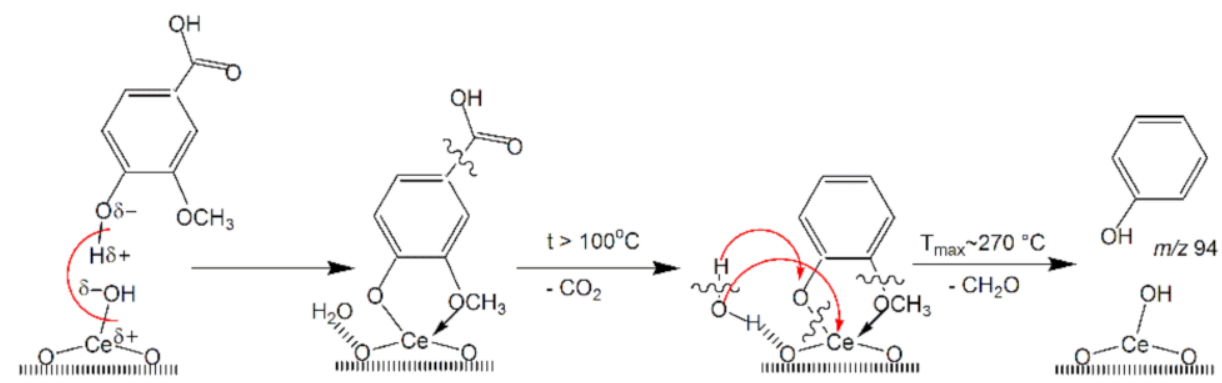

Scheme 2. The decomposition of the phenolic complex of VA.

The ion with $m / z 151$ was observed in the mass spectra of the $\mathrm{VA} / \mathrm{CeO}_{2}$ sample in a wide temperature range $\left(150-450{ }^{\circ} \mathrm{C}\right.$ ) (Figure $\left.9 \mathrm{~A}\right)$. $\mathrm{T}_{\max }$ of TPD peak for this ion was located at $\sim 380^{\circ} \mathrm{C}$ (Figure 9D). The presence of this peak could be related to the formation of the vanillin (M.r. = $152 \mathrm{Da}, m / z 151$ (100\%), $m / z 152$ (93\%), $m / z 81$ (32\%), m/z 109 (25\%), and $m / z 123(18 \%)$ [83]). Vanillin can form due to the VA reduction processes on the nanoceria surface.

The DTG/DTA/TG data obtained during the pyrolysis of the $\mathrm{VA} / \mathrm{CeO}_{2}$ sample are shown in Figure 10. Thermal decomposition of the sample proceeded in three main stages and continued in the range from 100 to $500^{\circ} \mathrm{C}$. All stages were exothermic.

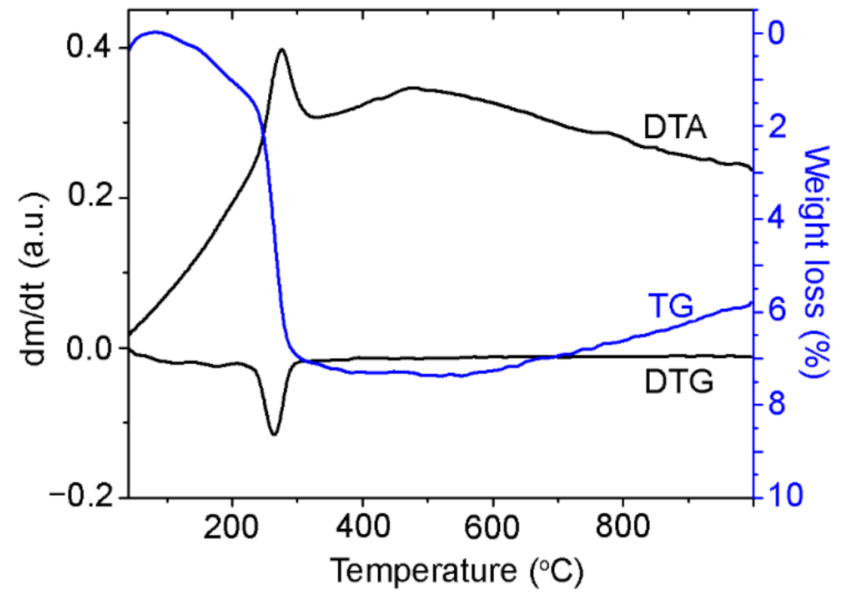

Figure 10. Differential thermal analysis (DTA), differential thermogravimetric analysis (DTG), and thermogravimetric (TG) curves for VA/ $\mathrm{CeO}_{2}$.

Analysis of the results of the TG/DTG and TPD MS studies shows that the greatest weight loss occurred during the decomposition of the carboxylate complexes with the release of guaiacol $\left(\mathrm{T}_{\max }=265^{\circ} \mathrm{C}\right)($ Table 7$)$. 
Table 7. Pyrolysis yields for TGA pyrolysis of $\mathrm{VA} / \mathrm{CeO}_{2}(0.6 \mathrm{mmol} / \mathrm{g})$.

\begin{tabular}{ccccc}
\hline Sample & Stage & $\mathbf{T}_{\max }\left({ }^{\circ} \mathbf{C}\right)$ & Volatiles (\%) & Char (\%) \\
\hline $\mathrm{VA} / \mathrm{CeO}_{2}$ & I & 115 & 4.3 & \\
$\mathrm{VA} / \mathrm{CeO}_{2}$ & II & 175 & 10.9 & 21.8 \\
$\mathrm{VA} / \mathrm{CeO}_{2}$ & $\mathrm{III}$ & 265 & 63.0 & \\
$\mathrm{VA} / \mathrm{CeO}_{2}$ & $\Sigma(\mathrm{I}+\mathrm{II}+\mathrm{III})$ & & 78.2 & \\
\hline
\end{tabular}

\subsubsection{Ferulic Acid}

The results of the TPD MS study of the FA/ $\mathrm{CeO}_{2}$ sample are presented in Figures 11 and 12. According to Figure 11, the main decomposition products were the 3-methoxy-4-vinyl phenol $(\mathrm{MVPh})\left(\right.$ M.r. $=150 \mathrm{Da}, m / z 150, \mathrm{~T}_{\max } \approx 110$ and $\left.220^{\circ} \mathrm{C}\right)$, guaiacol $(\mathrm{Mr}=124 \mathrm{Da}$, $\left.m / z 124, \mathrm{~T}_{\max } \approx 261{ }^{\circ} \mathrm{C}\right)$, 4-Vinylmethylguaiacol $\left(\mathrm{Mr}=164 \mathrm{Da}, \mathrm{m} / z 164, \mathrm{~T}_{\max } \approx 334{ }^{\circ} \mathrm{C}\right)$ and hydroxybenzene $\left(\mathrm{Mr}=94 \mathrm{Da}, m / z 94, \mathrm{~T}_{\max } \approx 407^{\circ} \mathrm{C}\right)$. The decomposition of the sample occurred from 55 to $700{ }^{\circ} \mathrm{C}$ (Figure 12A,B).
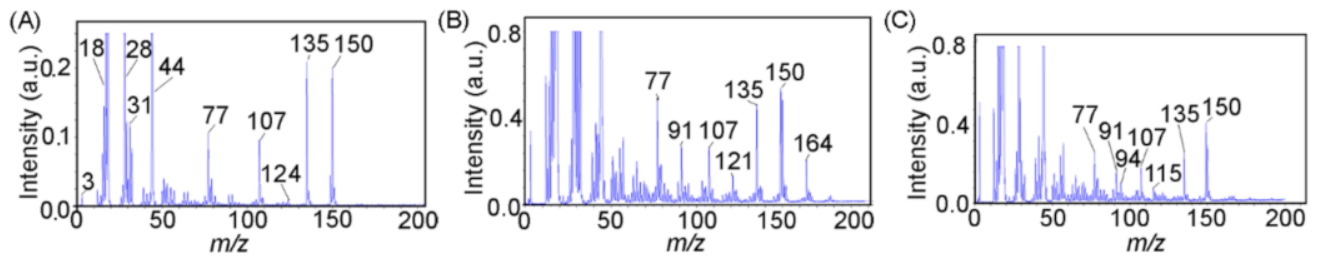

Figure 11. Mass spectra obtained by decomposition of $\mathrm{FA} / \mathrm{CeO}_{2}$ at a temperature of $250{ }^{\circ} \mathrm{C}(\mathrm{A})$, $330{ }^{\circ} \mathrm{C}(\mathbf{B})$, and $400{ }^{\circ} \mathrm{C}(\mathbf{C})$.
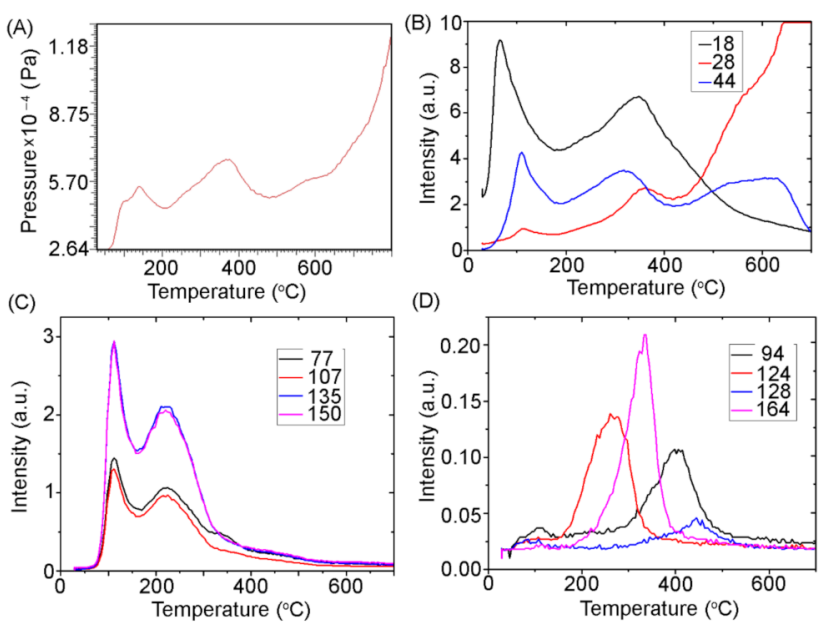

Figure 12. Thermal decomposition of $\mathrm{FA} / \mathrm{CeO} 2(0.6 \mathrm{mmol} / \mathrm{g})$; vapor pressure measured as a function of temperature for the $\mathrm{FA} / \mathrm{CeO}_{2}$ sample (A); TPD curves for ions with $m / z 18$, 24, and 44 (B), for ions with $m / z 77,107,135$, and 150 (C) and for ions with $m / z$ 94, 108, 124, 128, and 164 (D).

The MVPh was formed as a result of the decarboxylation of FA. The TPD curve of the MVPh molecular ion had two peaks at 110 and $220{ }^{\circ} \mathrm{C}$ (Figure 12C). During the decomposition of FA in the pristine state in the air atmosphere, the release of MVPh was registered at $280{ }^{\circ} \mathrm{C}$ [22]. Conversely, during the TPD MS study, its formation was observed at $\mathrm{T}_{\max } 480{ }^{\circ} \mathrm{C}$ [23]. The temperature maximum rate of the $\mathrm{MVF}$ formation on the $\mathrm{SiO}_{2}$ surface corresponded to $400{ }^{\circ} \mathrm{C}$ [50]. Thus, the interaction of FA with the $\mathrm{CeO}_{2}$ surface led to a significant decrease in the temperature of the MVPh formation. The release of the MVPh at $\mathrm{T}_{\max }=110{ }^{\circ} \mathrm{C}$ may be associated with the decomposition of monodentate carboxylate complexes (Scheme 3) and the destruction of FA associates (Scheme 4), the presence of which was evidenced by the FT-IR spectra of FA/CeO . The presence of 
associates was indicated by bands at 1666, $1691(\mathrm{C}=\mathrm{O}), 1325 \beta(\mathrm{COH})$, and at $949 \mathrm{~cm}^{-1}$ $\delta(\mathrm{COH})$, which were revealed in the IR-spectra of the samples FA/CeO $2(0.6-1.2 \mathrm{mmol} / \mathrm{g})$ (Figure 4).

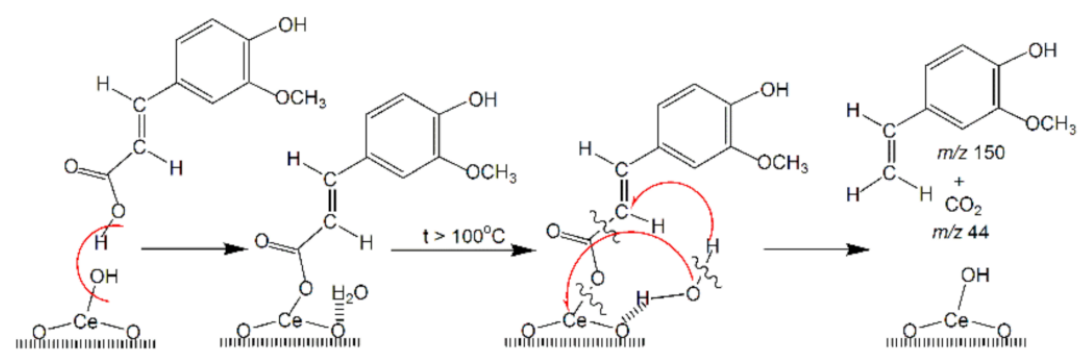

Scheme 3. The decomposition of the monodentate carboxylate complexes of FA.

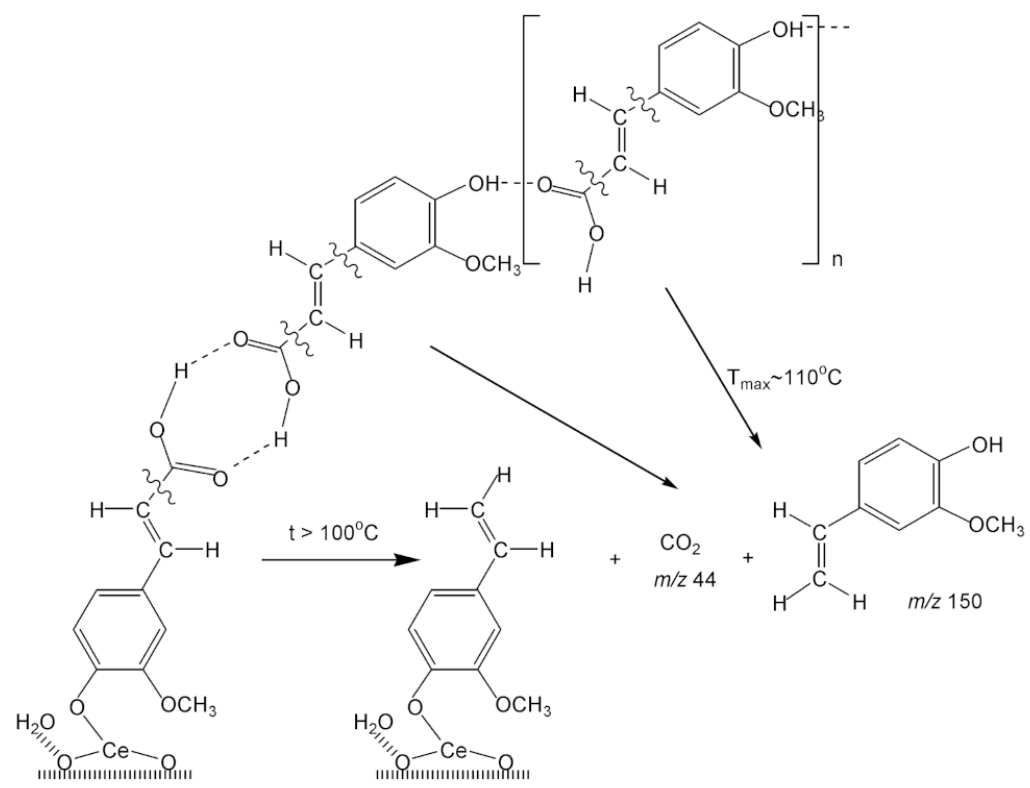

Scheme 4. The decomposition of FA associates.

The second peak $\left(\sim 220^{\circ} \mathrm{C}\right)$ was formed due to the transformation of the bidentate carboxylate complexes (Scheme 5). The second peak $\left(\sim 220^{\circ} \mathrm{C}\right)$ was formed due to the transformation of the bidentate carboxylate complexes (Scheme 5), which were detected in the IR spectroscopic study of $\mathrm{FA} / \mathrm{CeO}_{2}$ by the appearance of bands $v\left(\mathrm{COO}^{-}\right)$at 1405,1450 , and $1502 \mathrm{~cm}^{-1}$.

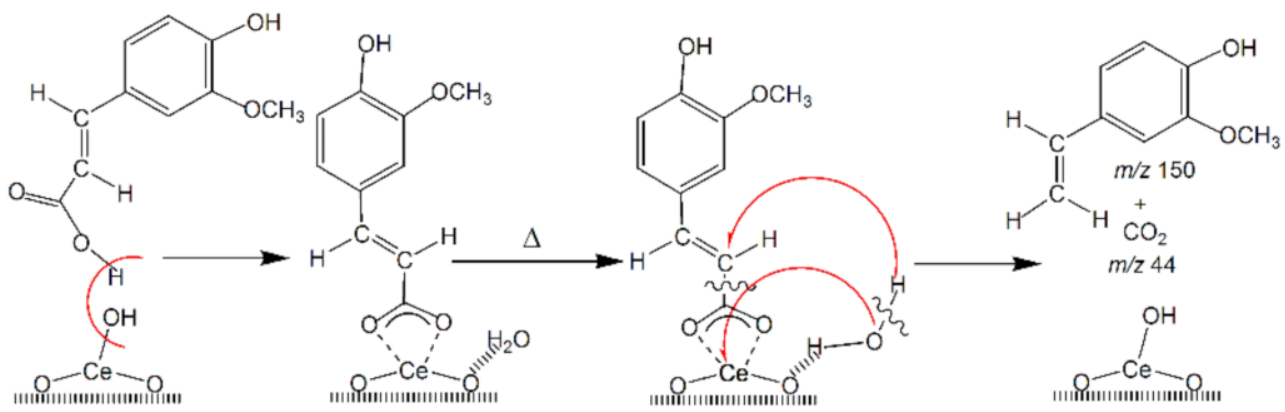

Scheme 5. The decomposition of the bidentate carboxylate complexes of FA.

Increasing the amount of FA on the oxide surface, the first TPD peak of the MVPh desorption increased compared to the second (Figure 13). In this case, the relative intensity of 
the absorption band $\left(1608 \mathrm{~cm}^{-1}\right)$ corresponding to $\mathrm{C}=\mathrm{O}$ vibrations of VA molecules, which form monodentate carboxylate complexes, also increased in the IR spectra of $\mathrm{FA} / \mathrm{CeO}_{2}$ (Figure 4). This indicated an increase in the relative amount of these complexes at higher acid concentrations.

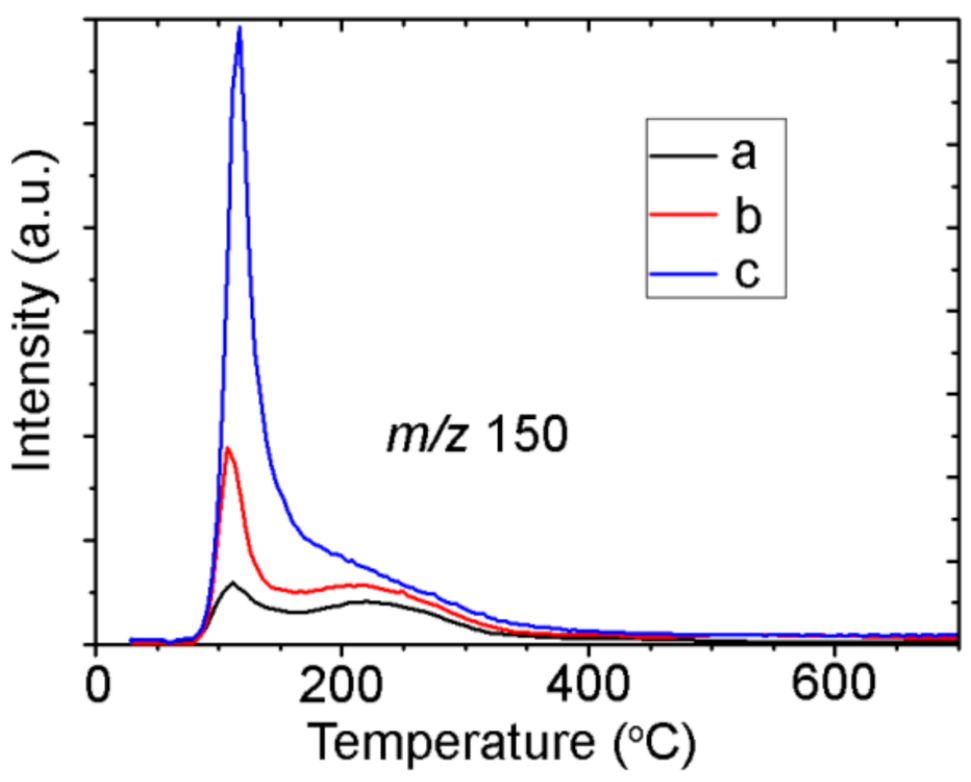

Figure 13. TPD-curves for the ion with $m / z 150$ (3-methoxy-4-vinilphenol), obtained by thermal decomposition of samples of $\mathrm{FA} / \mathrm{CeO}_{2}$ (a: $0.6 \mathrm{mmol} / \mathrm{g}$, b: $0.9 \mathrm{mmol} / \mathrm{g}$, c: $1.2 \mathrm{mmol} / \mathrm{g}$ ).

The destruction of FA complexes formed on the surface of $\mathrm{CeO}_{2}$ with the participation of aromatic ligands was accompanied by the release of guaiacol (M.r. $=124 \mathrm{Da}, m / z 124$ ) (Scheme 6) and hydroxybenzene (M.r. = $94 \mathrm{Da}, \mathrm{m} / z$ 94) (Figure 12D). The participation in the interaction with the oxide of both active groups of the aromatic ring was confirmed by the obtained data of FTIR spectroscopy, presented in Figure 4. The thermal transformation of FA molecules bound to the oxide surface through the $\mathrm{OCH}_{3}$ group occurred with the formation of guaiacol (M.r. $=124 \mathrm{Da}, m / z 124, \mathrm{~T}_{\max } \approx 265^{\circ} \mathrm{C}$ ).

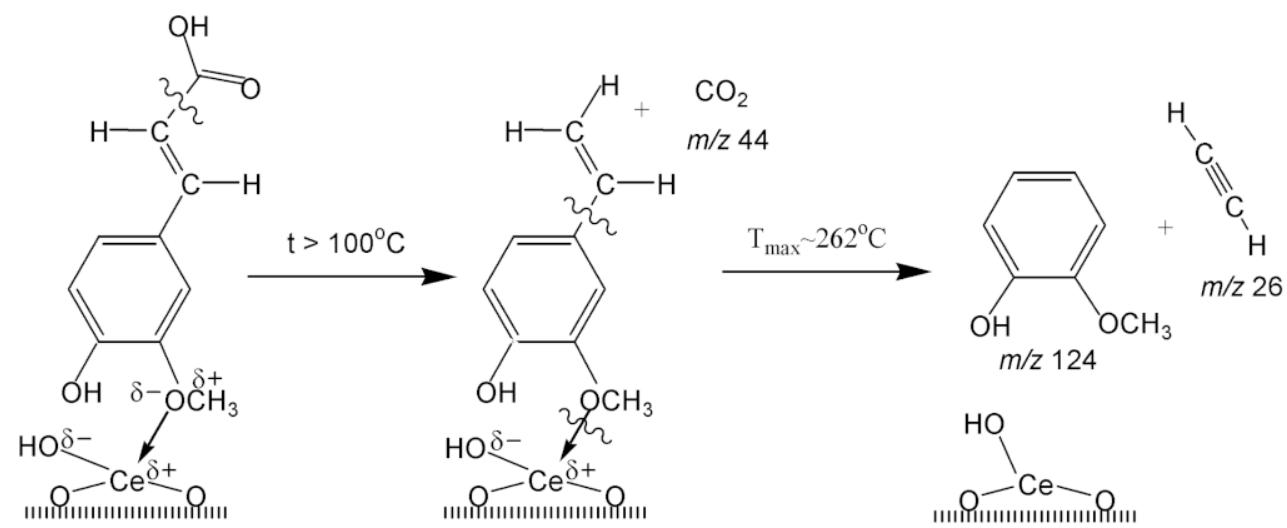

Scheme 6. The guaiacol formation.

FA complexes formed due to the simultaneous interaction of $\mathrm{OH}$ and $\mathrm{OCH}_{3}$ groups of the aromatic ring with the $\mathrm{CeO}_{2}$ surface being destroyed at about $400{ }^{\circ} \mathrm{C}$ (Scheme 7). As a result, hydroxybenzene was formed (M.r. $=94 \mathrm{Da}, m / z 94, \mathrm{~T}_{\max } \approx 407^{\circ} \mathrm{C}$ ) (Figure 12D). In the same way, similar complexes of caffeic acid decomposed on the $\mathrm{CeO}_{2}$ surface [79]. 


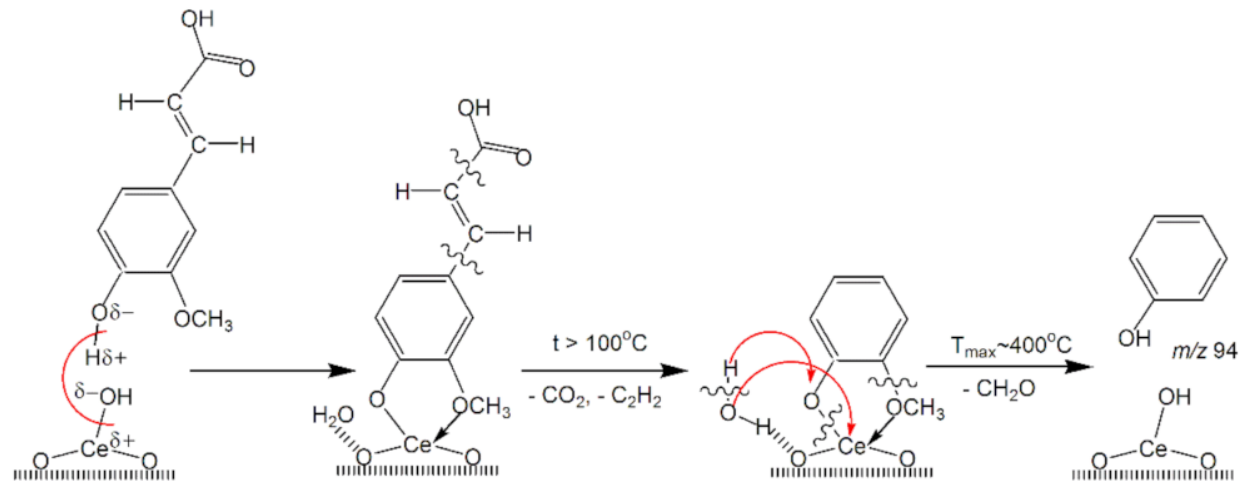

Scheme 7. The hydroxybenzene formation.

In addition, the presence of the TPD peak for the ions with $m / z 164$ and 178 may be due to the methylation processes of the aromatic ring, according to the Scheme 7, with the formation of methylated 4-vinylguaiacols (Figure 14, Scheme 8).

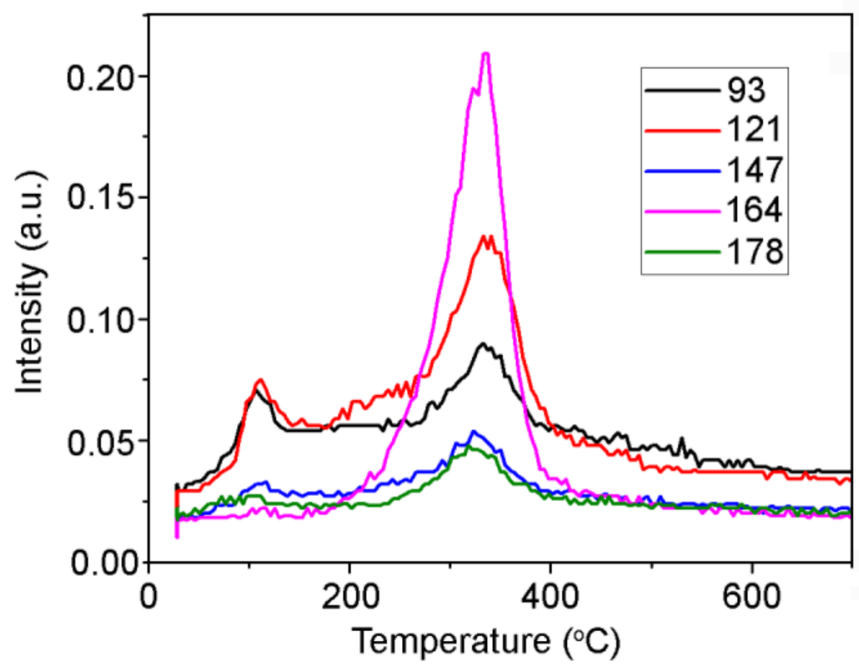

Figure 14. TPD-curves for the ion with $m / z$ 93, 121, 147, 164, and 178, obtained by thermal decomposition of samples of $\mathrm{FA} / \mathrm{CeO}_{2}$.

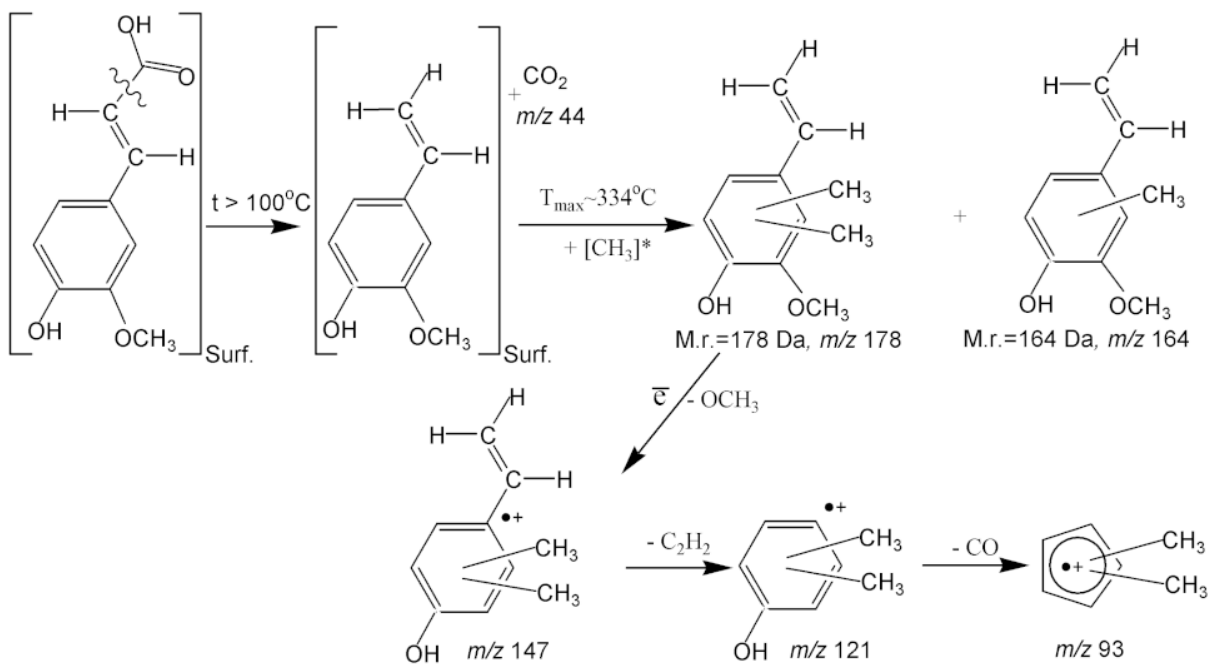

Scheme 8. The methylated 4-vinylguaiacols formation. 
At higher temperatures, desorption of aromatic products such as naphthalene $(\mathrm{m} / \mathrm{z}$ $128, \mathrm{~T}_{\max } \approx 430^{\circ} \mathrm{C}$ ) was detected (Figure $12 \mathrm{D}$ ). However, the intensity of their release was low. The formation of polyaromatic products was also detected during the pyrolysis of caffeic and ferulic acids and a number of coumarins on the surfaces of nanoscale oxides [50, 80,84]. However, the decomposition of cinnamic acid on the $\mathrm{SiO}_{2}$ surface did not reveal such products [85]. Therefore, their formation was seemingly due to the transformation of complexes bound to the oxide through the active groups of the aromatic ring.

In accordance with DTG/DTA/TG data obtained by pyrolysis of the $\mathrm{FA} / \mathrm{CeO}_{2}$ sample (Figure 15), the decomposition of FA occurred in the temperature range of 100 to $500{ }^{\circ} \mathrm{C}$ in four stages. All stages were exothermic. The maximum weight loss corresponded to the third stage $\left(\sim 259^{\circ} \mathrm{C}\right)($ Table 8$)$.

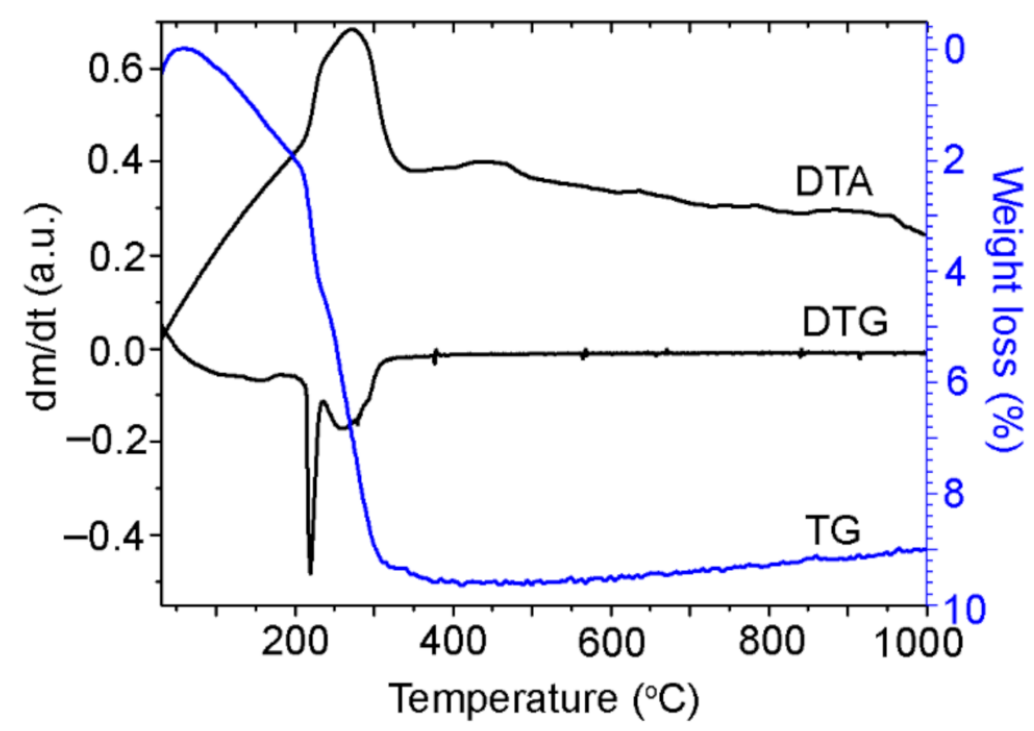

Figure 15. Differential thermal analysis (DTA), differential thermogravimetric analysis (DTG), and thermogravimetric (TG) curves for $\mathrm{FA} / \mathrm{CeO}_{2}$.

Table 8. Pyrolysis yields for TGA pyrolysis of FA/ $\mathrm{CeO}_{2}(0.6 \mathrm{mmol} / \mathrm{g})$.

\begin{tabular}{ccccc}
\hline Sample & Stage & $\mathbf{T}_{\max }\left({ }^{\circ} \mathbf{C}\right)$ & Volatiles (\%) & Char (\%) \\
\hline & I & 120 & 7.7 & \\
FA $/ \mathrm{CeO}_{2}$ & II & 158 & 11.5 & 12.6 \\
& III & 219 & 23.0 & \\
& IV & 259 & 45.2 & \\
\hline
\end{tabular}

3.2.5. Kinetic Parameters of the Catalytic Reactions of Vanillic and Ferulic Acids during Pyrolysis over Nanoceria Catalyst

The kinetic parameters of the formation of the main products during VA and FA catalytic pyrolysis were calculated in this study (Table 9). Based on calculated negative values of activation entropy, the formation processes of phenol, guaiacol, cresol, and methylated 4-vinylguaiacols run through highly ordered cyclic transition states on the nanoceria surface. 


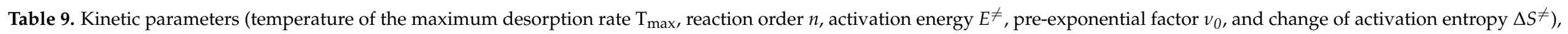
temperature range $\left(\mathrm{T}_{\text {range }}\right)$ of formation and peak intensities (I) of the catalytic reactions of vanillic and ferulic acids during pyrolysis over nanoceria catalyst.

\begin{tabular}{|c|c|c|c|c|c|c|c|c|c|c|}
\hline $\begin{array}{l}\text { Pyrolysis Product or } \\
\text { Its Fragment Ion }\end{array}$ & Scheme & $m / z^{1}$ & $I$, a.u. & $T_{\text {range }}$ & $T_{\max },{ }^{\circ} \mathrm{C}$ & $\mathbf{n}$ & $E^{\neq}, \mathrm{kJ} / \mathrm{mol}$ & $\begin{array}{l}v_{0} \\
\mathrm{~s}^{-1}\end{array}$ & $\begin{array}{c}\Delta S^{\neq} \\
\mathrm{cal} /(\mathbf{K} \times \mathbf{m o l})\end{array}$ & $R^{22}$ \\
\hline \multicolumn{11}{|c|}{ FA } \\
\hline Phenol & 7 & 94 & 0.107 & $250-570$ & 407 & 1 & 118 & $5.013 \times 10^{6}$ & -29 & 0.949 \\
\hline Guaiacol & 6 & 124 & 0.139 & $150-375$ & 260 & 1 & 78 & $1.665 \times 10^{5}$ & -36 & 0.957 \\
\hline \multirow{2}{*}{ 4-Vinylguaiacol } & 2 & 150 & 3.0 & $70-200$ & 120 & - & - & - & - & - \\
\hline & 3 & 150 & 2.2 & $100-400$ & 220 & - & - & - & - & - \\
\hline 4-Vinylmethylguaiacol & 8 & 164 & 0.209 & $188-427$ & 332 & 1 & 109 & $1.628 \times 10^{7}$ & -27 & 0.984 \\
\hline 4-Vinyldimethylguaiacol & 8 & 178 & 0.047 & $237-432$ & 318 & 1 & 114 & $4.200 \times 10^{7}$ & -25 & 0.951 \\
\hline Naphthalene & - & 128 & 0.04 & $320-520$ & 430 & - & - & - & - & - \\
\hline \multicolumn{11}{|c|}{ VA } \\
\hline Phenol & 2 & 94 & 0.05 & $295-471$ & 382 & 1 & 121 & $1.371 \times 10^{7}$ & -27 & 0.965 \\
\hline Cresol & - & 108 & 0.023 & $238-374$ & 322 & 1 & 137 & $3.383 \times 10^{9}$ & -16 & 0.944 \\
\hline Guaiacol & & 124 & 0.067 & $193-390$ & 275 & 1 & 91 & $1.575 \times 10^{6}$ & -31 & 0.938 \\
\hline Vanillin & - & 151 & 0.026 & $180-420$ & $\sim 271$ & - & - & - & - & - \\
\hline
\end{tabular}

${ }^{1} \mathrm{~m} / \mathrm{z}$ : ratio of ion mass to ion charge. ${ }^{2} R^{2}$ : coefficient of determination. 
The formation of phenol was characterized by similar kinetic parameters for both vanillic and ferulic acids. The value of the activation energy was $\sim 120 \mathrm{~kJ} \mathrm{~mol}^{-1}$, and the change in the entropy of activation is $\sim 28-29\left(\mathrm{cal} \mathrm{K}^{-1} \mathrm{~mol}^{-1}\right)$. Close kinetic parameters were observed for the formation of guaiacol for both vanillic and ferulic acids. This indicates that FA and VA have common pyrolysis pathways, probably due to thermal transformations of the same types of surface complexes. The processes of the formation of methylated products such as cresol in the case of VA and methylated 4-vinylguaiacols in the case of FA are also characterized by close temperatures of the maximum desorption rate of $\sim 318-332{ }^{\circ} \mathrm{C}$ (Table 8 ).

\section{Conclusions}

The interactions of model compounds of lignin ( $\mathrm{P}, \mathrm{G}, \mathrm{VA}$, and FA) with the nanoceria surface were investigated by FT-IR spectroscopy. It was found that active groups of the aromatic ring $\left(\left(-\mathrm{OH}_{\mathrm{ar}}\right)\right.$ and $\left.\left(-\mathrm{OCH}_{3}\right)_{\mathrm{ar}}\right)$ as well as carboxylate groups, in the case of VA and FA, were involved in the interaction with the oxide. According to the FT-IR spectra, VA formed carboxylate complexes with a bidentate structure on the $\mathrm{CeO}_{2}$ surface. In contrast, for FA, in addition to bidentate complexes, the existence of monodentate complexes was confirmed.

Thermal decomposition of $\mathrm{P}$ and $\mathrm{G}$ bound to the nanoceria surface through the $\mathrm{OH}$ group was probably accompanied by hydrogenation of the aromatic ring and its opening. The intensity of these processes was low. As a result of the thermal destruction of G complexes formed through the methoxyl group, hydroxybenzene was released. The thermal decomposition of $\mathrm{P}$ and $\mathrm{G}$ revealed signs of alkylation of the oxide surface. Catalytic pyrolysis of guaiacol and pyrocatechol led to the deep destruction of these compounds. The decomposition of carboxylic acids was accompanied by active processes of dehydration, decarbonylation, and decarboxylation. The main pyrolysis products of VA on the nanoceria surface were guaiacol and hydroxybenzene. Guaiacol can be formed due to the destruction of carboxylate complexes and the complexes formed through $\mathrm{OH}$ - and $\mathrm{CH}_{3} \mathrm{O}$-groups of the aromatic ring. Destruction of FA carboxylate complexes led to the formation of 3-methoxy4 -vinylphenol. As a result of the transformation of the complexes formed through $\mathrm{OH}$ and $\mathrm{CH}_{3} \mathrm{O}$-groups of the aromatic ring, guaiacol, and hydroxybenzene were formed. The decomposition of carboxylate complexes occurred at lower temperatures than complexes formed through $\mathrm{OH}-$ and $\mathrm{CH}_{3} \mathrm{O}$-groups. Thermolysis of both acids was accompanied by alkylation of the oxide surface. Polycyclic aromatic hydrocarbons (naphthalene) were also registered during the FA catalytic pyrolysis.

The kinetic parameters of the formation of the main products' catalytic pyrolysis (phenol, guaiacol, cresol, and methylated 4-vinylguaiacols) were calculated. The catalytic pyrolysis processes of VA and FA occurred through highly ordered cyclic transition states on the nanoceria surface.

Author Contributions: Conceptualization, T.K., M.K. and M.L.; methodology, N.N., B.P. and T.K.; investigation, N.N., B.P., T.C. and T.K.; resources, T.K.; writing-original draft preparation, N.N. and T.K.; writing-review and editing, N.N., T.K., J.L. and M.L.; visualization, N.N., T.K., and B.P.; supervision, M.K., T.K., J.L. and M.L.; project administration, T.K. and J.L.; funding acquisition, T.K. and M.L. All authors have read and agreed to the published version of the manuscript.

Funding: This publication is based on work supported by grant FSA3-20-66700 from the United States Civilian Research \& Development Foundation (CRDF Global) with funding from the United States Department of State, by the Swedish Research Council (VR) under contract 348-2014-4250, by STCU (grant P707), and by NAS of Ukraine (program "new functional substances and materials of chemical production").

Institutional Review Board Statement: Not applicable.

Informed Consent Statement: Not applicable.

Data Availability Statement: The study did not report any data. 
Conflicts of Interest: The authors declare no conflict of interest.

\section{References}

1. Isikgor, F.H.; Becer, C.R. Lignocellulosic biomass: A sustainable platform for the production of bio-based chemicals and polymers. Polym. Chem. 2015, 6, 4497-4559. [CrossRef]

2. Van Wyk, J.P.H. Biotechnology and the utilization of biowaste as a resource for bioproduct development. TRENDS Biotech. 2001, 19, 172-177. [CrossRef]

3. Chakar, F.S.; Ragauskas, A.J. Review of current and future softwood kraft lignin process chemistry. Ind. Crop. Prod. 2004, 20, 131-141. [CrossRef]

4. $\quad$ Linger, J.G.; Vardon, D.R.; Guarnieri, M.T.; Karp, E.M.; Hunsinger, G.B.; Franden, M.A.; Beckham, G.T. Lignin valorization through integrated biological funneling and chemical catalysis. Proc. Natl. Acad. Sci. USA 2014, 111, 12013-12018. [CrossRef]

5. Ragauskas, A.J.; Beckham, G.T.; Biddy, M.J.; Chandra, R.; Chen, F.; Davis, M.F.; Davison, B.H.; Dixon, R.A.; Gilna, P.; Keller, M.; et al. Lignin valorization: Improving lignin processing in the biorefinery. Science 2014, 344, 1246843. [CrossRef]

6. Tuck, C.O.; Pérez, E.; Horváth, I.T.; Sheldon, R.A.; Poliakoff, M. Valorization of biomass: Deriving more value from waste. Science 2012, 337, 695-699. [CrossRef] [PubMed]

7. Boerjan, W.; Ralph, J.; Baucher, M. Lignin biosynthesis. Annu. Rev. Plant Biol. 2003, 54, 519-546. [CrossRef]

8. Zakzeski, J.; Bruijnincx, P.C.; Jongerius, A.L.; Weckhuysen, B.M. The catalytic valorization of lignin for the production of renewable chemicals. Chem. Rev. 2010, 110, 3552-3599. [CrossRef]

9. Mathers, R.T. How well can renewable resources mimic commodity monomers and polymers? J. Polym. Sci. Part A Polym. Chem. 2012, 50, 1-15. [CrossRef]

10. Zhang, Z.; Song, J.; Han, B. Catalytic transformation of lignocellulose into chemicals and fuel products in ionic liquids. Chem. Rev. 2017, 117, 6834-6880. [CrossRef] [PubMed]

11. Li, G.; Luo, Z.; Wang, W.; Cen, J. A Study of the Mechanisms of Guaiacol Pyrolysis Based on Free Radicals Detection Technology. Catalysts 2020, 10, 295. [CrossRef]

12. Yefremova, S.; Zharmenov, A.; Sukharnikov, Y.; Bunchuk, L.; Kablanbekov, A.; Anarbekov, K.; Kulik, T.; Nikolaichuk, A.; Palianytsia, B. Rice husk hydrolytic lignin transformation in carbonization process. Molecules 2019, 24, 3075. [CrossRef]

13. Wang, H.; Tucker, M.; Ji, Y. Recent development in chemical depolymerization of lignin: A review. J. Appl. Chem. 2013, 2013, 838645. [CrossRef]

14. Ormond, T.K.; Baraban, J.H.; Porterfield, J.P.; Scheer, A.M.; Hemberger, P.; Troy, T.P.; Ahmed, M.; Nimlos, M.R.; Robichaud, D.J.; Daily, J.W.; et al. Thermal decompositions of the lignin model compounds: Salicylaldehyde and catechol. J. Phys. Chem. A 2018, 122, 5911-5924. [CrossRef] [PubMed]

15. González-Baró, A.C.; Parajón-Costa, B.S.; Franca, C.A.; Pis-Diez, R. Theoretical and spectroscopic study of vanillic acid. J. Mol. Struct. 2008, 889, 204-210. [CrossRef]

16. Totong, S.; Daorattanachai, P.; Laosiripojana, N.; Idem, R. Catalytic depolymerization of alkaline lignin to value-added phenolicbased compounds over $\mathrm{Ni} / \mathrm{CeO}_{2}-\mathrm{ZrO}_{2}$ catalyst synthesized with a one-step chemical reduction of $\mathrm{Ni}$ species using $\mathrm{NaBH} 4$ as the reducing agent. Fuel Process. Technol. 2020, 198, 106248. [CrossRef]

17. Cheng, H.; Wu, S.; Huang, J.; Zhang, X. Direct evidence from in situ FTIR spectroscopy that o-quinonemethide is a key intermediate during the pyrolysis of guaiacol. Anal. Bioanal. Chem. 2017, 409, 2531-2537. [CrossRef]

18. Bertero, M.; Gorostegui, H.A.; Orrabalis, C.J.; Guzmán, C.A.; Calandri, E.L.; Sedran, U. Characterization of the liquid products in the pyrolysis of residual chañar and palm fruit biomasses. Fuel 2014, 116, 409-414. [CrossRef]

19. Furimsky, E. Catalytic hydrodeoxygenation. Appl Catal. A Gen. 2000, 199, 147-190. [CrossRef]

20. Hemberger, P.; Custodis, V.B.; Bodi, A.; Gerber, T.; van Bokhoven, J.A. Understanding the mechanism of catalytic fast pyrolysis by unveiling reactive intermediates in heterogeneous catalysis. Nature Commun. 2017, 8, 15946. [CrossRef]

21. Mathew, S.; Abraham, T.E.; Sudheesh, S. Rapid conversion of ferulic acid to 4-vinyl guaiacol and vanillin metabolites by Debaryomyces hansenii. J. Mol. Catal. B Enzym. 2007, 44, 48-52. [CrossRef]

22. Fiddler, W.; Parker, W.E.; Wasserman, A.E.; Doerr, R.C. Thermal decomposition of ferulic acid. J. Agric. Food Chem. 1967, 15, 757-761. [CrossRef]

23. Kulik, T.V.; Barvinchenko, V.N.; Palyanytsya, B.B.; Lipkovska, N.A.; Dudik, O.O. Thermal transformations of biologically active derivatives of cinnamic acid by TPD MS investigation. J. Anal. Appl. Pyrol. 2011, 90, 219-223. [CrossRef]

24. Zhang, P.H.; Yu, X.Y.; Weng, L.X.; Sun, L.L.; Mao, Z.C.; Zhang, Y.L. Degradation of Ferulic Acid by the Endophytic Fungus Colletotrichum gloeosporioides TMTM-13 Associated with Ostrya rehderiana Chun. ACS Omega 2019, 4, 21000-21004. [CrossRef] [PubMed]

25. Lesage-Meessen, L.; Haon, M.; Delattre, M.; Thibault, J.F.; Ceccaldi, B.C.; Asther, M. An attempt to channel the transformation of vanillic acid into vanillin by controlling methoxyhydroquinone formation in Pycnoporus cinnabarinus with cellobiose. Appl. Microbiol. Biotechnol. 1997, 47, 393-397. [CrossRef]

26. Abdelkafi, S.; Sayadi, S.; Ali Gam, Z.B.; Casalot, L.; Labat, M. Bioconversion of ferulic acid to vanillic acid by Halomonas elongata isolated from table-olive fermentation. FEMS Microbiol. Lett. 2006, 262, 115-120. [CrossRef]

27. Ye, M.; Yue, T.; Yuan, Y. Evolution of polyphenols and organic acids during the fermentation of apple cider. J. Sci. Food Agric. 2014, 94, 2951-2957. [CrossRef] 
28. De Heredia, J.B.; Torregrosa, J.; Dominguez, J.R.; Peres, J.A. Kinetic model for phenolic compound oxidation by Fenton's reagent. Chemosphere 2001, 45, 85-90. [CrossRef]

29. Fiorentino, A.; Gentili, A.; Isidori, M.; Monaco, P.; Nardelli, A.; Parrella, A.; Temussi, F. Environmental effects caused by olive mill wastewaters: Toxicity comparison of low-molecular-weight phenol components. J. Agric. Food Chem. 2003, 51, 1005-1009. [CrossRef]

30. Sayadi, S.; Allouche, N.; Jaoua, M.; Aloui, F. Detrimental effects of high molecular-mass polyphenols on olive mill wastewater biotreatment. Process Biochem. 2000, 35, 725-735. [CrossRef]

31. Ramos-Cormenzana, A.; Juarez-Jimenez, B.; Garcia-Pareja, M.P. Antimicrobial activity of olive mill wastewaters (alpechin) and biotransformed olive oil mill wastewater. Int. Biodeterior. Biodegrad. 1996, 38, 283-290. [CrossRef]

32. Xie, X.G.; Dai, C.C. Degradation of a model pollutant ferulic acid by the endophytic fungus Phomopsis liquidambari. Biores. Technol. 2015, 179, 35-42. [CrossRef]

33. Sudarsanam, P.; Peeters, E.; Makshina, E.V.; Parvulescu, V.I.; Sels, B.F. Advances in porous and nanoscale catalysts for viable biomass conversion. Chem. Soc. Rev. 2019, 48, 2366-2421. [CrossRef]

34. Kabakcı, S.B.; Hacıbektaşoğlu, Ş. Catalytic Pyrolysis of Biomass. Pyrolysis 2017, 7, 167-196. [CrossRef]

35. Schimming, S.M.; LaMont, O.D.; König, M.; Rogers, A.K.; D'Amico, A.D.; Yung, M.M.; Sievers, C. Hydrodeoxygenation of guaiacol over ceria-zirconia catalysts. ChemSusChem 2015, 8, 2073-2083. [CrossRef]

36. Deng, W.; Zhang, H.; Wu, X.; Li, R.; Zhang, Q.; Wang, Y. Oxidative conversion of lignin and lignin model compounds catalyzed by $\mathrm{CeO}_{2}$-supported Pd nanoparticles. Green Chem. 2015, 17, 5009-5018. [CrossRef]

37. Ohta, H.; Kobayashi, H.; Hara, K.; Fukuoka, A. Hydrodeoxygenation of phenols as lignin models under acid-free conditions with carbon-supported platinum catalysts. Chem. Commun. 2011, 47, 12209-12211. [CrossRef]

38. Grams, J.; Niewiadomski, M.; Ryczkowski, R.; Ruppert, A.M.; Kwapiński, W. Activity and characterization of Ni catalyst supported on $\mathrm{CeO}_{2}-\mathrm{ZrO}_{2}$ for thermo-chemical conversion of cellulose. Int. J. Hydrogen Energy 2016, 41, 8679-8687. [CrossRef]

39. Song, W.L.; Dong, Q.; Hong, L.; Tian, Z.Q.; Tang, L.N.; Hao, W.; Zhang, H. Activating molecular oxygen with Au/CeO2 for the conversion of lignin model compounds and organosolv lignin. RSC Adv. 2019, 9, 31070-31077. [CrossRef]

40. Yoshikawa, T.; Shinohara, S.; Yagi, T.; Ryumon, N.; Nakasaka, Y.; Tago, T.; Masuda, T. Production of phenols from lignin-derived slurry liquid using iron oxide catalyst. Appl. Catal. B Environ. 2014, 146, 289-297. [CrossRef]

41. Fronzi, M.; Soon, A.; Delley, B.; Traversa, E.; Stampfl, C. Stability and morphology of cerium oxide surfaces in an oxidizing environment: A first-principles investigation. J. Chem. Phys. 2009, 131, 104701. [CrossRef]

42. Spanier, J.E.; Robinson, R.D.; Zhang, F.; Chan, S.W.; Herman, I.P. Size-dependent properties of $\mathrm{CeO}_{2}-\mathrm{y}$ nanoparticles as studied by Raman scattering. Phys. Rev. B 2001, 64, 245407. [CrossRef]

43. Mortensen, P.M.; Grunwaldt, J.D.; Jensen, P.A.; Jensen, A.D. Screening of catalysts for hydrodeoxygenation of phenol as a model compound for bio-oil. ACS Catal. 2013, 3, 1774-1785. [CrossRef]

44. Zaytseva, Y.A.; Panchenko, V.N.; Simonov, M.; Shutilov, A.; Zenkovets, G.; Renz, M.; Simakova, I. Effect of Gas Atmosphere on Catalytic Behaviour of Zirconia, Ceria and Ceria Zirconia Catalysts in Valeric Acid Ketonization. Top. Catal. 2013, 56, 846-855. [CrossRef]

45. Kulyk, K.; Palianytsia, B.; Alexander, J.; Azizova, L.; Borysenko, M.; Larsson, M.; Kartel, M.; Kulik, T. Kinetics of Valeric Acid Ketonization and Ketenization in Catalytic Pyrolisis on Nanosized $\mathrm{SiO}_{2}, \gamma-\mathrm{Al}_{2} \mathrm{O}_{3} \mathrm{CeO}_{2} / \mathrm{SiO}_{2}, \mathrm{Al}_{2} \mathrm{O}_{3} / \mathrm{TiO}_{2}$ and $\mathrm{TiO}_{2} / \mathrm{Al}_{2} \mathrm{O}_{3}$. Chem. Phys. Chem. 2017, 18, 1943-1955. [CrossRef] [PubMed]

46. Kulik, T.; Palianytsia, B.; Larsson, M. Catalytic Pyrolysis of Aliphatic Carboxylic Acids into Symmetric Ketones over Ceria-Based Catalysts: Kinetics, Isotope Effect and Mechanism. Catalysts 2020, 10, 179. [CrossRef]

47. Lange, J.P.; Price, R.; Ayoub, P.M.; Louis, J.; Petrus, L.; Clarke, L.; Gosselink, H. Valeric biofuels: A platform of cellulosic transportation fuels. Angew. Chem. Int. Ed. 2010, 49, 4479-4483. [CrossRef] [PubMed]

48. Li, S.; Deng, W.; Wang, S.; Wang, P.; An, D.; Li, Y.; Zhang, Q.; Wang, Y. Catalytic transformation of cellulose and its derivatives into functionalized organic acids. ChemSusChem 2018, 11, 1995-2028. [CrossRef]

49. Barvinchenko, V.N.; Lipkovskaya, N.A.; Kulik, T.V. Adsorption of Natural 3-Phenylpropenic Acids on Cerium Dioxide Surface. Colloid J. 2019, 81, 1-7. [CrossRef]

50. Kulik, T.V.; Lipkovska, N.A.; Barvinchenko, V.N.; Palyanytsya, B.B.; Kazakova, O.A.; Dovbiy, O.A.; Pogorelyi, V.K. Interactions between bioactive ferulic acid and fumed silica by UV-vis spectroscopy, FT-IR, TPD MS investigation and quantum chemical methods. J. Colloid Interface Sci. 2009, 339, 60-68. [CrossRef]

51. Janković, I.A.; Šaponjić, Z.V.; Čomor, M.I.; Nedeljković, J.M. Surface modification of colloidal TiO2 nanoparticles with bidentate benzene derivatives. J. Phys. Chem. C 2009, 113, 12645-12652. [CrossRef]

52. Connor, P.A.; Dobson, K.D.; McQuillan, A.J. New sol-gel attenuated total reflection infrared spectroscopic method for analysis of adsorption at metal oxide surfaces in aqueous solutions. Chelation of $\mathrm{TiO}_{2}, \mathrm{ZrO}_{2}$, and $\mathrm{Al}_{2} \mathrm{O}_{3}$ surfaces by catechol, 8-quinolinol, and acetylacetone. Langmuir 1995, 11, 4193-4195. [CrossRef]

53. Bobkova, E.Y.; Vasilyeva, V.S.; Ksenofontov, M.A.; Ostrovskaya, L.E.; Shundalov, M.B. Spectral and energy characteristics of dihydroxybenzenes in the crystalline state. Bull. BSU Ser. Phys. 2009, 3, 7-13.

54. Nelson, N.C.; Manzano, J.S.; Sadow, A.D.; Overbury, S.H.; Slowing, I.I. Selective hydrogenation of phenol catalyzed by palladium on high-surface-area ceria at room temperature and ambient pressure. ACS Catal. 2015, 5, 2051-2061. [CrossRef] 
55. Singh, V.; Naka, T.; Takami, S.; Sahraneshin, A.; Togashi, T.; Aoki, N.; Adschiri, T. Hydrothermal synthesis of inorganic-organic hybrid gadolinium hydroxide nanoclusters with controlled size and morphology. Dalton Trans. 2013, 42, 16176-16184. [CrossRef]

56. Huang, W.; Jiang, P.; Wei, C.; Zhuang, D.; Shi, J. Low-temperature one-step synthesis of covalently chelated ZnO/dopamine hybrid nanoparticles and their optical properties. J. Mater. Res. 2008, 23, 1946-1952. [CrossRef]

57. Hachani, R.; Lowdell, M.; Birchall, M.; Hervault, A.; Mertz, D.; Begin-Colin, S.; Thanh, N.T.K. Polyol synthesis, functionalisation, and biocompatibility studies of superparamagnetic iron oxide nanoparticles as potential MRI contrast agents. Nanoscale 2016, 8 , 3278-3287. [CrossRef] [PubMed]

58. Togashi, T.; Naka, T.; Asahina, S.; Sato, K.; Takami, S.; Adschiri, T. Surfactant-assisted one-pot synthesis of superparamagnetic magnetite nanoparticle clusters with tunable cluster size and magnetic field sensitivity. Dalton Trans. 2011, 40, 1073-1078. [CrossRef]

59. Dugandžić, I.M.; Jovanović, D.J.; Mančić, L.T.; Zheng, N.; Ahrenkiel, S.P.; Milošević, O.B.; Nedeljković, J.M. Surface modification of submicronic TiO2 particles prepared by ultrasonic spray pyrolysis for visible light absorption. J. Nanopart. Res. 2012, 14, 1157. [CrossRef]

60. Janković, I.A.; Šaponjić, Z.V.; Džunuzović, E.S.; Nedeljković, J.M. New hybrid properties of TiO 2 nanoparticles surface modified with catecholate type ligands. Nanoscale Res. Lett. 2010, 5, 81-88. [CrossRef]

61. Savić, T.D.; Janković, I.A.; Šaponjić, Z.V.; Čomor, M.I.; Veljković, D.Ž.; Zarić, S.D.; Nedeljković, J.M. Surface modification of anatase nanoparticles with fused ring catecholate type ligands: A combined DFT and experimental study of optical properties. Nanoscale 2012, 4, 1612-1619. [CrossRef]

62. Wang, X.; Zhu, S.; Wang, S.; Wang, J.; Fan, W.; Lv, Y. Ni nanoparticles entrapped in nickel phyllosilicate for selective hydrogenation of guaiacol to 2-methoxycyclohexanol. Appl. Catal. A Gen. 2018, 568, 231-241. [CrossRef]

63. Wang, X.; Zhu, S.; Wang, S.; He, Y.; Liu, Y.; Wang, J.; Lv, Y. Low temperature hydrodeoxygenation of guaiacol into cyclohexane over $\mathrm{Ni} / \mathrm{SiO} 2$ catalyst combined with $\mathrm{H} \beta$ zeolite. RSC Adv. 2019, 9, 3868-3876. [CrossRef]

64. Nakanishi, K. Infrared Adsorption Spectroscopy; Practical; Holden Day: San Francisco, CA, USA, 1962; p. 216.

65. Clavijo, E.; Menéndez, J.R.; Aroca, R. Vibrational and surface-enhanced Raman spectra of vanillic acid. J. Raman Spectrosc. Int. J. Orig. Work Asp. Raman Spectrosc. Incl. High. Order Process. Brillouin Rayleigh Scatt. 2008, 39, 1178-1182. [CrossRef]

66. Khvan, A.M.; Kristallovich, E.L.; Abduazimov, K.A. Complexation of caffeic and ferulic acids by transition-metal ions. Chem. Nat. Comp. 2001, 37, 72-75. [CrossRef]

67. Sharpe, E.; Frasco, T.; Andreescu, D.; Andreescu, S. Portable ceria nanoparticle-based assay for rapid detection of food antioxidants (NanoCerac). Analyst 2013, 138, 249-262. [CrossRef]

68. Palacios, E.G.; Juárez-López, G.; Monhemius, A.J. Infrared spectroscopy of metal carboxylates: II. Analysis of Fe (III), Ni and Zn carboxylate solutions. Hydrometallurgy 2004, 72, 139-148. [CrossRef]

69. Yost, E.C.; Tejedor-Tejedor, M.I.; Anderson, M.A. In situ CIR-FTIR characterization of salicylate complexes at the goethite/aqueous solution interface. Environ. Sci. Technol. 1990, 24, 822-828. [CrossRef]

70. Tunesi, S.; Anderson, M.A. Surface effects in photochemistry: An in situ cylindrical internal reflection-Fourier transform infrared investigation of the effect of ring substituents on chemisorption onto titania ceramic membranes. Langmuir 1992, 8, 487-495. [CrossRef]

71. Parrino, F.; Augugliaro, V.; Camera-Roda, G.; Loddo, V.; López-Muñoz, M.J.; Márquez-Álvarez, C.; Palmisano, G.; Palmisano, L.; Puma, M.A. Visible-light-induced oxidation of trans-ferulic acid by $\mathrm{TiO}_{2}$ photocatalysis. J. Catal. 2012, 295, 254-260. [CrossRef]

72. Sebastian, S.; Sundaraganesan, N.; Manoharan, S. Molecular structure, spectroscopic studies and first-order molecular hyperpolarizabilities of ferulic acid by density functional study. Spectrochim. Acta A 2009, 74, 312-323. [CrossRef]

73. Ferrer, E.G.; Salinas, M.V.; Correa, M.J.; Vrdoljak, F.; Williams, P.A.M. ALP Inhibitors: Vanadyl(IV) Complexes of Ferulic and Cinnamic Acid. Z. Naturforsch 2005, 305-311. [CrossRef]

74. Kalinowska, M.; Piekut, J.; Bruss, A.; Follet, C.; Sienkiewicz-Gromiuk, J.; Świsłocka, R.; Rzączyńska, Z.; Lewandowski, W. Spectroscopic (FT-IR, FT-Raman,1H,13C NMR, UV/VIS), thermogravimetric and antimicrobial studies of Ca(II), Mn(II),Cu(II), $\mathrm{Zn}(\mathrm{II})$ and Cd(II) complexes of ferulic acid. Spectrochim. Acta A Mol. Biomol. Spectrosc. 2014, 122, 631-638. [CrossRef] [PubMed]

75. Świsłocka, R.; Regulska, E.; Samsonowicz, M.; Lewandowski, W. Experimental and theoretical study on benzoic acid derivatives. J. Molec. Struct. 2013, 1044, 181-187. [CrossRef]

76. Lebedev, A.T. Mass Spectrometry in Organic Chemistry; Binom: Moscow, Russia, 2003; p. 493.

77. Zhao, C.; He, J.; Lemonidou, A.A.; Li, X.; Lercher, J.A. Aqueous-phase hydrodeoxygenation of bio-derived phenols to cycloalkanes. J. Catal. 2011, 280, 8-16. [CrossRef]

78. Sharma, R.K.; Bakhshi, N.N. Catalytic upgrading of biomass-derived oils to transportation fuels and chemicals. Can. J. Chem. Eng. 1991, 69, 1071-1081. [CrossRef]

79. Nastasiienko, N.; Palianytsia, B.; Kartel, M.; Larsson, M.; Kulik, T. Thermal Transformation of Caffeic Acid on the Nanoceria Surface Studied by Temperature Programmed Desorption Mass-Spectrometry, Thermogravimetric Analysis and FT-IR Spectroscopy. Colloids Interfaces 2019, 3, 34. [CrossRef]

80. Kulik, T.V.; Lipkovska, N.O.; Barvinchenko, V.M.; Palyanytsya, B.B.; Kazakova, O.A.; Dudik, O.O.; Menyhárd, A.; László, K. Thermal transformation of bioactive caffeic acid on fumed silica seen by UV-Vis spectroscopy, thermogravimetric analysis, temperature programmed desorption mass spectrometry and quantum chemical methods. J. Colloid Interface Sci. 2016, 470, 132-141. [CrossRef] 
81. Sato, S.; Koizumi, K.; Nozaki, F. Ortho-selective methylation of phenol over $\mathrm{CeO}_{2}$ catalyst. Appl. Catal. A Gen. 1995, 133, L7-L10. [CrossRef]

82. Wandas, R.; Surygala, J.; Śliwka, E. Conversion of cresols and naphthalene in the hydroprocessing of three-component model mixtures simulating fast pyrolysis tars. Fuel 1996, 75, 687-694. [CrossRef]

83. NIST Chemistry Web Book. NIST Standard Reference Database Number 69. Available online: https://webbook.nist.gov/ chemistry (accessed on 24 June 2021).

84. Kulyk, K.; Ishchenko, V.; Palyanytsya, B.; Khylya, V.; Borysenko, M.; Kulyk, T. A TPD-MS study of the interaction of coumarins and their heterocyclic derivatives with a surface of fumed silica and nanosized oxides $\mathrm{CeO}_{2} / \mathrm{SiO}_{2}, \mathrm{TiO}_{2} / \mathrm{SiO}_{2}, \mathrm{Al}_{2} \mathrm{O}_{3} / \mathrm{SiO}_{2}$. J. Mass Spectrom. 2010, 45, 750-761. [CrossRef] [PubMed]

85. Kulik, T.V.; Barvinchenko, V.N.; Palyanitsa, B.B.; Smirnova, O.V.; Pogorelyi, V.K.; Chuiko, A.A. A desorption mass spectrometry study of the interaction of cinnamic acid with a silica surface. Russ. J. Phys. Chem. 2007, 8, 83-90. [CrossRef] 